\title{
Isotopic studies of the Upper and Middle Rio Grande. Part 2 - Salt loads and human impacts in south New Mexico and west Texas
}

\author{
Anna Szynkiewicz, ${ }^{1,2,}$, David M. Borrok ${ }^{3,2}$, Girisha K. Ganjegunte ${ }^{4}$, Grzegorz Skrzypek ${ }^{5}$, Lin Ma ${ }^{2}$, \\ Michael Rearick ${ }^{6}$, George Perkins ${ }^{6}$ \\ ${ }^{1}$ University of Tennessee, Earth and Planetary Sciences, 1412 Circle Drive, Knoxville, TN, USA \\ ${ }^{2}$ University of Texas at El Paso, Geological Sciences, 500 W. University Ave., El Paso, TX, USA \\ ${ }^{3}$ School of Geosciences, University of Louisiana at Lafayette, 611 McKinley St., P.O. Box 44650, \\ Lafayette, LA 70504, USA \\ ${ }^{4}$ Texas AgriLife Research Center, Texas A\&M University System, El Paso, TX, USA \\ ${ }^{5}$ West Australian Biogeochemistry Centre, School of Plant Biology, The University of Western Australia, \\ 35 Stirling Highway, Crawley WA 6009, Australia \\ ${ }^{6}$ EES-14 Earth System Observations, Los Alamos National Laboratory, Los Alamos, NM 87545, USA \\ *corresponding author: aszynkie@ utk.edu, phone: 865-974-6006, fax: 865-974-2368
}

\section{Abstract}

Increasing groundwater and soil salinity is a threat to the land and water resources in arid regions. Global warming will likely increase salinity of dryland river systems. In order to characterize salt loading into the semi-arid portion of the Rio Grande in south New Mexico and west Texas, we sampled seasonally (2009-2011) the river, agricultural drains, and saline groundwater. In addition to major element chemistry, these samples were analyzed for sulfur and oxygen isotope compositions $\left(\delta^{34} \mathrm{~S}\right.$ and $\left.\delta^{18} \mathrm{O}\right)$ of dissolved $\mathrm{SO}_{4}$ and in some cases for nitrogen and oxygen isotope compositions $\left(\delta^{15} \mathrm{~N}\right.$ and $\left.\delta^{18} \mathrm{O}\right)$ of dissolved $\mathrm{NO}_{3}$. Uranium isotopes $\left({ }^{234} \mathrm{U} /{ }^{238} \mathrm{U}\right.$ activity ratio) were also measured for selected samples. The natural inflow of basinal brines/groundwater $\left(\delta^{34} \mathrm{~S}\right.$ of +8 to $\left.+11 \%\right)$ in the semi-arid Rio Grande study area was minor in the investigated seasons and could not be detected by the $\delta^{34} \mathrm{~S}$ mass balance. However, we did find localized increases of $\delta^{34} \mathrm{~S}(+2$ to $+5 \%$ ) in the Rio Grande that were attributable to salt loads from the intersections of agricultural drains with the water table of a natural salt flat and associated evaporative brine $\left(\delta^{34} \mathrm{~S}\right.$ of $\left.+12 \%\right)$ in the shallow subsurface. In the areas, with higher water use for land irrigation, the $\delta^{34} \mathrm{~S}$ of the river and drain water was relatively consistent (from $\sim 0$ to $+2 \%$ ) compared to the $\delta^{18} \mathrm{O}$ (from $\sim+2$ to $+6 \%$ ). Most likely, this resulted from application of S-rich fertilizers (e.g., ammonium sulfates, elemental $\mathrm{S}$, sulfuric acid) with low $\delta^{34} \mathrm{~S}\left(-2\right.$ to $+4 \%$ ) and high $\delta^{18} \mathrm{O}(+9$ to $+16 \%$ ). Additionally, we observed considerably lower $\delta^{18} \mathrm{O}\left(\mathrm{SO}_{4}\right)$ in the Rio Grande and agricultural drains $(<7$ $\%$ ) compared to geologic and anthropogenic $\mathrm{SO}_{4}$ sources (+9 to $+16 \%$ ), which likely resulted from microbial recycling of $\mathrm{SO}_{4}$ in soil of the irrigated land related to assimilatory sulfate reduction. Shallow recharge to the Rio Grande was also inferred from the lower ${ }^{234} \mathrm{U} /{ }^{238} \mathrm{U}$ activity ratios (1.62 to 1.88) compared to deeper groundwater (2.54 to 2.64) and the distinctive $\delta^{15} \mathrm{~N}$ and $\delta^{18} \mathrm{O}$ values of nitrates ( +5 to $+25 \%$ and -5 to $+15 \%$, respectively) typical for septic effluents that are undergoing denitrification. 
Agricultural practices during flood irrigation intensify evaporation of the Rio Grande surface water and considerably increase water salinity. This process is also important in the evolution of water chemistry toward a Na-SO $\mathrm{S}_{4}$-Cl-rich composition and precipitation of secondary calcite in soil profiles.

\section{Introduction}

The Rio Grande is the major source of water for flood irrigation in southern New Mexico and west Texas (Ellis et al. 1993). The Rio Grande surface water is diverted to cultivated fields through a complex system of canals and some of this water is subsequently returned to the river via a network of agricultural drains and/or shallow groundwater recharge (Fig. 1). High water use is particularly concentrated in the semi-arid portions of the middle Rio Grande from central/south New Mexico below Elephant Butte Dam through far west Texas (Fig. 2). At present, high salt loads within the riverine hydrologic system greatly decrease the water quality and the crop productivity (e.g., Picchioni et al., 2000; Ganjegunte et al., 2011; Simpson et al., 2014).

One of the biggest uncertainties related to salt loads in the Rio Grande is their poorly-defined sources and how agricultural practices contribute to the increasing salinity. Currently, there are large disagreements among scientists, stakeholders, and government agencies on the extent to which the salinity of the Rio Grande is controlled by natural versus anthropogenic processes. Flows of deeplyderived, saline fluids through a complex network of faults and upwelling of brines at the termini of geologic sub-basins (Process A on Fig. 1) are believed to be major natural sources of salinity in the Rio Grande watershed (Phillips et al., 2003; Hogan et al., 2007; Williams et al., 2013). In addition, enhanced evapotranspiration rates (Philips et al., 2003) coupled with flood irrigation and the application of fertilizers are also thought to be important anthropogenic factors (Processes B-C on Fig. 1) for increased salt loads in the Rio Grande (Wilcox, 1957; Trock et al., 1978; Szynkiewicz et al., 2011).

The transition to a more arid climate, followed by increasing evaporation rates and decreasing stream flows that are predicted for the American Southwest (e.g., Gutzler and Robbins, 2010), will further degrade the already overstressed water resources in the Rio Grande watershed. Moreover, population centers that utilize water in this area of the Rio Grande valley like Las Cruces, New Mexico, El Paso, Texas, and Juárez, Mexico, (Fig. 2) continue to grow. Questions are arising about how to meet increasing water demand in a system plagued by dwindling surface water and high salt loads. Therefore, the problem of delineating the sources of salt loading in the Rio Grande is becoming critical, as this is the first step in understanding how to address these challenges. In this study, we report new geochemical data (elemental, and sulfur $(\mathrm{S})$, oxygen $(\mathrm{O})$, nitrogen $(\mathrm{N})$, and uranium $(\mathrm{U})$ isotopes) for surface water and groundwater samples collected seasonally between 2009 and 2011. We use these data to evaluate the relative 
importance of different sources of salts linked to natural processes and anthropogenic activities. Furthermore, we discuss the respective roles of these processes and how they might affect future management practices designed to prevent further salinization of water resources.

\section{Environmental Setting}

The Rio Grande flows through a series of alluvial-fill basins formed by half grabens that were formed during the Rio Grande rift 30 Ma ago during an episode of widespread extension of the western United States (Keller and Baldridge, 1999). These basins are filled with alluvial, fluvial, playa, and lacustrine sediments derived from erosion of adjacent Precambrian crystalline and Paleozoic sedimentary bedrock highlands and range in depth from less than $30 \mathrm{~m}$ to 4,000 $\mathrm{m}$ (Keller and Cather, 1994). The majority of recharge to the Rio Grande occurs in the spring from snowmelt in the headwater region in southwest Colorado and in the high mountain areas of north New Mexico (Ellis et al., 1993). Further, smaller recharge to the Rio Grande occurs during summer monsoon. Average annual precipitation delivered to the semi-arid stretch of the Rio Grande is less than $254 \mathrm{~mm}$ (Ellis et al., 1993) and decreases southward reaching less than $203 \mathrm{~mm}$ in El Paso, Texas.

In the studied semi-arid area of south New Mexico and West Texas (Fig. 2), the Rio Grande is regulated by the Elephant Butte and Caballo reservoirs in central/south New Mexico. In addition to its widespread agricultural use, the Rio Grande surface water of the studied area is partly used by the cities of Las Cruces, New Mexico and El Paso, Texas, to supplement aquifer groundwater for municipal purposes. The flow volume and the water quality of the Rio Grande decrease downstream (e.g., Hogan et al., 2007; Szynkiewicz et al., 2011). Elevated salt concentrations and low flows preclude the use of Rio Grande water for agricultural and municipal purposes during the non-irrigation season (October through February) when water is being stored in the Elephant Butte reservoir. In many locations, the Rio Grande River disappears entirely from the surface. During these times, agricultural drains and municipal waste effluents from the cities of Las Cruces and El Paso become the major tributaries to the Rio Grande below Elephant Butte Dam. Conversely, in the irrigation season (March through September) stream flows increase (and salt concentrations decrease) when water is released for irrigation downstream of Elephant Butte and Caballo reservoirs.

The irrigation system(s) in the Rio Grande basin is a complex network of shallow irrigation canals (above the water table) combined with deeply cut channels (drains) that are incised to the groundwater table. The canals move irrigation water to individual agricultural fields, while the drains alleviate salt build up during flood irrigation. Eventually, these drains flow back to the Rio Grande (e.g., Anderholm 2002). 
This paper is mainly focused on the stretch of the Rio Grande valley in the Mesilla basin, between Radium Springs, New Mexico and west El Paso, Texas (Fig. 2). In El Paso, the Rio Grande becomes an international border of the United States with Mexico. Various security measures on the border precluded us from some surface water sampling in this area in 2009-2011. Nevertheless, we expanded our sampling campaigns to the agricultural drains located further east and south of El Paso in Fabens and Tornillo, Texas (Fig. 2). These drains are major flow contributors to the Rio Grande along the international border, thus, their water quality is reflective of that of the Rio Grande.

\section{Methods}

\subsection{Field sampling}

Between June of 2010 and March of 2011 surface water samples were collected monthly at locations 16 through 20, and from four agricultural (Loc.46-48, 50) and two drains in west El Paso (Loc. 50-51; Fig. 2). The drains in west El Paso comprise a combination of flows from agricultural drains and storm drains. In the studied Rio Grande stretch ( 100 km long) intense agriculture practices take place in the Rio Grande valley. Additionally, seasonal water samples were collected in two agricultural drains $\sim 60 \mathrm{~km}$ south of El Paso, Texas, in Fabens and Tornillo, Texas (Loc. 53-54; Fig. 2). Waste water effluents were also collected from Las Cruces (Loc. 57), New Mexico, and west El Paso, Texas (Loc. 58-59).

In addition to surface water samples in the Rio Grande, drains, and waste effluents, we sampled several locations thought to be representative of the saline groundwater endmembers previously indicated as important in increasing the salinity of the Rio Grande (e.g., Witcher et al., 2004; Hibbs and Merino, 2006; Hogan et al., 2007). These included saline geothermal water from an artesian well $\left(41^{\circ} \mathrm{C}\right)$ in Truth or Consequences, south New Mexico (Loc. 77$)$, brackish groundwater from a municipal well $\left(27^{\circ} \mathrm{C}\right)$ used by the El Paso Desalination Plant, Texas (Loc. 85), and saline packets (lenses) of groundwater underlying the agricultural fields near Fabens, Texas (Loc. 86-88).

In all locations, the sampled water was filtered in the field with a $0.45 \mu \mathrm{m}$ nylon filter into two 125 $\mathrm{mL}$ plastic bottles. One bottle was acidified with 16 drops of high-purity concentrated $\mathrm{HNO}_{3}$ for cation and uranium (U) isotope analyses. The second portion was left untreated for anion analysis. Unfiltered surface water samples were collected in 0.25-1.0 L plastic bottles that were rinsed three times with the sample water prior to collection. These were processed and analyzed for the $\mathrm{S}$ and $\mathrm{O}$ isotope compositions of dissolved sulfate $\left(\mathrm{SO}_{4}\right)$. Temperature, $\mathrm{pH}$, and conductivity were measured in situ for surface water and groundwater samples using an Orion portable meter (Thermo Scientific 3 Star Multimeter). Alkalinity was measured in the field using a LaMotte titration kit (LaMotte Company, Maryland, USA) with analytical error of $\pm 4 \mathrm{mg} / \mathrm{L}$. 


\subsection{Fertilizers}

Liquid and solid samples of fertilizers were obtained from the Helena Fertilizer company/distributor located in Tornillo, Texas (Loc. 54; Fig. 2). Additionally, the samples of fertilizers containing pure gypsum and elemental $\mathrm{S}$ were obtained from a local farmer living in the same area. The chemical analyses of the Helena fertilizers were done by Actlabs Life Sciences in Ancaster, Ontario, Canada. For S and O isotope analyses, the fertilizers were dissolved in DI-water. Afterward, the dissolved $\mathrm{SO}_{4}$ was precipitated as $\mathrm{BaSO}_{4}$ by reaction with $10-20 \mathrm{~mL}$ of $10 \% \mathrm{BaCl}_{2}$ and analyzed for $\delta^{34} \mathrm{~S}$ and $\delta^{18} \mathrm{O}$ as described below. The fertilizers containing gypsum and elemental $\mathrm{S}$ were analyzed for $\mathrm{S}$ isotopes as mineral phases without prior laboratory treatment.

\subsection{Chemical analyses}

The concentrations of major cations in all water samples were measured using a Perkin Elmer 5300 DV Inductively Coupled Plasma-Optical Emission Spectrometer (ICP-OES) at the University of Texas at El Paso. Samples (diluted with de ionized water to $1: 10,1: 100$ or 1:1000) were analyzed using multielement atomic adsorption standards (diluted from $10.00 \mathrm{mg} / \mathrm{L}$ stock solutions) and the U.S. Geological Survey standard reference water samples were used as external checks of precision and accuracy. The concentrations of anions in all water samples were measured using EPA method 300 on a Dionex DX-600 equipped with conductivity detection at Los Alamos National Laboratory. An AG14 guard column and AS14 separator column were used in conjunction with a Dionex ASRS 300 2mm suppressor to separate the anion species and reduce the background conductivity. The mobile phase composition was $3.5 \mathrm{mM}$ $\mathrm{Na}_{2} \mathrm{CO}_{3}$ and $1.0 \mathrm{mM} \mathrm{NaHCO}$. Calibration standards were prepared from a stock solution of anions purchased from SPEX Certiprep(C. Samples were diluted and re-run in cases where elemental concentrations were outside the initial calibration range. Because of required dilution, particularly for the samples of river/drain/well water showing higher salinity (conductivities in the range of $1-5 \mathrm{mS} / \mathrm{cm}$ ), the analytical uncertainty was considerably higher (10 to $20 \%$ ) as compared to the water samples with lower ion concentrations that did not require as much dilution. The concentrations of $\mathrm{NO}_{3}$ and $\mathrm{PO}_{4}$ were measured using a Hach DR 2800 spectrophotometer accompanied by TNT835 and PhosVer® kits.

\section{4. $S$ and $O$ isotope analysis}

All collected surface water and groundwater samples were analyzed for the $\mathrm{S}$ and $\mathrm{O}$ isotope compositions of their dissolved $\mathrm{SO}_{4}\left(\delta^{34} \mathrm{~S}\right.$ and $\delta^{18} \mathrm{O}$, respectively). After arrival in the laboratory, raw water samples were filtered, acidified with $\mathrm{HCl}$, and dissolved $\mathrm{SO}_{4}$ was precipitated as $\mathrm{BaSO}_{4}$ by reaction with $10-20 \mathrm{~mL}$ of $10 \% \mathrm{BaCl}_{2}$. Prior to drying, the $\mathrm{BaSO}_{4}$ precipitate was rinsed several times with DIwater. The $\delta^{34} \mathrm{~S}$ of $\mathrm{BaSO}_{4}$ was determined using an EA1110 elemental analyzer coupled to a Finnigan 
Mat 252 isotope ratio mass spectrometer via a ConFlo II split interface in the Stable Isotope Research Facility at Indiana University. S isotopic data are reported with respect to VCDT (Vienna Cañon Diablo Troilite). Analytical reproducibility was better than $0.3 \%$ based on sample duplicates. Given that the water samples were not filtered in situ in the field, we subsequently repeated precipitation of $\mathrm{BaSO}_{4}$ on several samples stored in the refrigerator $\left(4^{\circ} \mathrm{C}\right)$ for 3-4 months. Consequently, the measured $\delta^{34} \mathrm{~S}$ of $\mathrm{BaSO}_{4}$ was within the analytical error of $+/-0.3 \%$ compared to the $\mathrm{BaSO}_{4}$ of water samples processed a few hours after sampling.

The $\delta^{18} \mathrm{O}$ of $\mathrm{BaSO}_{4}$ was analyzed in a continuous flow system using a high temperature conversion elemental analyzer (TC/EA) coupled with a Delta XL Mass Spectrometer (Thermo-Fisher Scientific, Bremen, Germany) at the University of Western Australia. $\mathrm{BaSO}_{4}$ was thermally decomposed in a highlyreductive environment and $\delta^{18} \mathrm{O}$ was analyzed in the $\mathrm{CO}$ gas yielded, which was carried in helium stream. The raw $\delta$-values were normalized using a multipoint normalization technique (Skrzypek and Sadler 2011; Skrzypek, 2013) based on international standards (IAEA601, IAEA602, SO-5, SO-6 and NBS127) provided by International Atomic Energy Agency from Vienna (IAEA). Analytical reproducibility was better than $0.3 \%$ based on duplicates.

\section{5. $N$ and $O$ isotope analysis}

Water samples were analyzed for aqueous nitrate nitrogen and oxygen isotope ratios using a modified version of the microbial denitrification technique described by Casciotti et al. (2002) and Sigman et al. (2001) using Pseudomonas aurofaciens (ATCC 13985). Stable nitrogen and oxygen isotope compositions were measured for $\mathrm{N}_{2} \mathrm{O}$ in continuous flow mode using a $\mathrm{GV}$ Instruments Isoprime isotope ratio mass spectrometer (GV Instruments, Manchester, UK) in the Los Alamos National Laboratory. Analytical linearity was monitored and corrected for by analyzing standards after every five samples. An analysis blank, consisting of the identical tryptic soy broth and $\mathrm{NaOH}$ solution used for samples was used in the blank correction procedure. All stable isotope ratios are reported in the standard $\delta$-notation as the per mil deviation (\%) relative to Vienna Standard Mean Ocean Water (VSMOW) for $\delta^{18} \mathrm{O}$ and atmospheric $\mathrm{N}_{2}$ for $\delta^{15} \mathrm{~N}$. A calibration curve for $\delta^{15} \mathrm{~N}$ was constructed using analyses of IAEA-NO-3 and USGS32 ( $\delta^{15} \mathrm{~N}_{\text {air }}=+4.7$ and $180 \%$ vs. atmospheric $\mathrm{N}_{2}$, respectively). $\delta^{18} \mathrm{O}$ values were calibrated using analyses of IAEA-NO-3 and USGS34 ( $\delta^{18} \mathrm{O}=+25.6 \%$ and $-30.9 \%$ vs. VSMOW, respectively). Within each analytical run, the precision on five replicates of standard solution IAEA-NO-3 was consistently $<0.25 \%$ for $\delta^{15} \mathrm{~N}$ and $<0.50 \%$ for $\delta^{18} \mathrm{O}$. 


\subsection{Uranium series isotope analysis}

We selected several surface water samples from the semi-arid portion of the Rio Grande (Loc. 9,10, $11,13,15,16,19,20)$ and drains (Loc. 49, 50, 54) sampled in 2009-2010 for U series isotope analysis. The site locations and general characterization of these samples have been presented in Szynkiewicz et al. (Part 1 - this volume). Additionally, three representative samples of groundwater with elevated salinity (Loc. 75, 77, 86) and two fertilizer samples (U 200 ppm) were analyzed. About $30 \mathrm{~g}$ of water sample and $\sim 100 \mathrm{mg}$ of fertilizer sample were weighed and spiked with an artificial ${ }^{233} \mathrm{U}$ tracer. Afterward, the fertilizer samples were fully dissolved using $\sim 2 \mathrm{~mL}$ concentrated ultrapure $\mathrm{HNO}_{3}$. All sample solutions were evaporated on hotplates. Afterward, the evaporated precipitate was dissolved in $1 \mathrm{~mL} 7.5 \mathrm{~N} \mathrm{HNO}_{3}$ and the $\mathrm{U}$ was separated from solution and purified using conventional cation exchange chromatography (Pelt et al., 2008; Ma et al., 2010). The U isotopic ratios $\left({ }^{234} \mathrm{U} /{ }^{238} \mathrm{U}\right.$ and ${ }^{233} \mathrm{U} /{ }^{238} \mathrm{U}$ ) were measured on a Nuplasma MC-ICP-MS using $25 \mathrm{ng}$ of $\mathrm{U}$ per sample. The measured $\left({ }^{233} \mathrm{U} /{ }^{238} \mathrm{U}\right)$ ratios allow for calculation of $\mathrm{U}$ concentrations in the original samples (Isotope dilution method). The standard-sample bracketing technique (with NBL 145B as the U bracketing solution) was used to correct for mass discrimination and drafting of ion counter/faraday cup gains during the measurements. Uncertainties on $U$ isotope ratios and U concentration were $\sim 1 \%$. USGS rock reference standard (BCR-2) was analyzed along with samples for data quality assurance. The Measured values for $B C R-2$ are: $\left({ }^{234} U /{ }^{238} U\right)=1.003 \pm 0.001$ and $U$ concentration $=1.686 \pm 0.010 \mathrm{ppm}(\mathrm{n}=2)$; both are in agreement with the reference values: BCR-2 $\left({ }^{234} \mathrm{U} /{ }^{238} \mathrm{U}\right)=1.000$ and $\mathrm{U}$ concentration $=1.69 \pm 0.02 \mathrm{ppm}$ (Sims et al., 2008). The $\mathrm{U}$ procedural blanks were $\sim 20 \mathrm{pg}$.

\subsection{Mass flux calculations}

Using a combination of online gauging station data collected from the U.S. Geological Survey, the U.S. International Boundary and Water Commission, and the El Paso County Water Improvement District No.1, we were able to reconstruct the volumetric flow rates for the Rio Grande at Canutillo (Loc. 19) and at west El Paso (Loc. 20), and for the agricultural drain in Tornillo (Loc. 53). Using these volumetric flow rates we were able to calculate elemental mass loads (Suppl. Tab. 1) by multiplying the stream water concentrations (in $\mathrm{mg} / \mathrm{L}$ ) by the flow rates (in $\mathrm{L} / \mathrm{s}$ ) and then converting the units to metric tons/day.

\subsection{Chemical modeling}

Saturation indices (SIs) for the formation of calcite, gypsum, thenardite and halite were calculated for the water samples using the geochemical modeling program, PHREEQCTM (Parkhurst and Appelo, 1999). Saturation indices are reported as the $\log$ of the ion activity product (IAP) divided by the equilibrium solubility product $\left(\mathrm{K}_{\mathrm{sp}}\right)$ for a given mineral phase. Using this convention, $\mathrm{SI}=0$ indicates equilibrium 
with respect to a mineral phase, and SI $>0$ and SI $<0$ represent oversaturation and undersaturation with, respectively.

\section{Results}

All in situ, chemical and isotope measurements for the studied Rio Grande, drain, groundwater, and waste water effluent samples are listed in Supplementary Table 1. The chemical, S and O isotope measurements for the studied fertilizers are listed in Table 1.

\subsection{Water Chemistry}

The electrical conductivity (EC) of the Rio Grande along the Mesilla basin (Loc. 16-20; Fig. 2) was lower in the irrigation season $(\sim 0.6-1.0 \mathrm{mS} / \mathrm{cm})$ compared to the non-irrigation season $(\sim 1.3-3.5 \mathrm{mS} / \mathrm{cm})$ (Suppl. Tab. 1). Consequently, a similar pattern was observed for concentrations of major ions. In the irrigation season, lower concentrations were observed for $\mathrm{SO}_{4}(\sim 100-180 \mathrm{mg} / \mathrm{L}), \mathrm{Cl}(\sim 45-90 \mathrm{mg} / \mathrm{L}), \mathrm{Na}$ ( 60-115 mg/L), $\mathrm{HCO}_{3}(\sim 130-170 \mathrm{mg} / \mathrm{L}), \mathrm{Ca}(\sim 55-75 \mathrm{mg} / \mathrm{L}), \mathrm{K}(\sim 5-10 \mathrm{mg} / \mathrm{L})$, and $\mathrm{Mg}(\sim 10-15 \mathrm{mg} / \mathrm{L})$ (Suppl. Tab. 1). In contrast, higher concentrations were observed in the non-irrigation season for $\mathrm{SO}_{4}$ ( 200-650 mg/L), Cl ( 150-520 mg/L), Na ( 150-740 mg/L), $\mathrm{HCO}_{3}(\sim 180-300 \mathrm{mg} / \mathrm{L}), \mathrm{Ca}(\sim 100-150$ $\mathrm{mg} / \mathrm{L}), \mathrm{K}(\sim 10-25 \mathrm{mg} / \mathrm{L})$, and $\mathrm{Mg}$ ( 20-45 mg/L). The agricultural drains south of El Paso, Texas showed considerably higher EC and concentration units $\left(\mathrm{EC} 1.4-4.6 \mathrm{mS} / \mathrm{cm}, \mathrm{SO}_{4} 250-750 \mathrm{mg} / \mathrm{L}, \mathrm{Cl} 155-770\right.$ $\mathrm{mg} / \mathrm{L}, \mathrm{HCO}_{3}$ 190-340 mg/L, Na 180-600 mg/L, Ca 80-280 mg/L, Mg 20-60 mg/L, K 10-35 mg/L) compared to the agricultural/city drains in the Mesilla basin (EC 1.0-2.5 mS/cm, SO $140-530 \mathrm{mg} / \mathrm{L}, \mathrm{Cl}$ 60-260 mg/L, $\mathrm{HCO}_{3}$ 150-355 mg/L, Na 130-325 mg/L, Ca 105-140 mg/L, Mg 10-35 mg/L, K 5-12 $\mathrm{mg} / \mathrm{L}$ ). Among all investigated drains, abnormally high EC was observed in the Montoya Drain (4.1 to $8.4 \mathrm{mS} / \mathrm{cm}$ ), a city drain of west El Paso, Texas (Loc. 49). During the summer of 2010, the Montoya Drain contained up to $\sim 1500 \mathrm{mg} / \mathrm{L}, \sim 1800 \mathrm{mg} / \mathrm{L}$, and $\sim 1350 \mathrm{mg} / \mathrm{L}$ of $\mathrm{SO}_{4}, \mathrm{Cl}$ and $\mathrm{Na}$, respectively (Suppl. Tab. 1). These concentrations measurably decreased to $\sim 680 \mathrm{mg} / \mathrm{L}, \sim 600 \mathrm{mg} / \mathrm{L}$, and $\sim 680 \mathrm{mg} / \mathrm{L}$, respectively, by the fall of 2010. Similarly high conductivity and concentrations of major ions were observed in the waste water effluents discharging to the Rio Grande in Las Cruces, New Mexico and west El Paso, Texas: EC 1.3-2.8 mS/cm, $\mathrm{SO}_{4} 120-530$ mg/L, Cl 115-310 mg/L, HCO 3 140-300 mg/L, Na 175365 mg/L, Ca 55-85 mg/L, Mg 10-45 mg/L, K 12-32 mg/L (Suppl. Tab. 1).

The $\mathrm{SO}_{4}$ versus $\mathrm{Cl}$ concentrations were positively correlated for the Rio Grande, drain, and waste effluent samples (Fig. 3A). A similar relationship was observed for the $\mathrm{SO}_{4}$ versus $\mathrm{HCO}_{3}$ concentrations (Fig. 3B).For comparison with our new chemical data (2010-2011), we call upon five previously measured geothermal groundwater samples (No. 78-82) from the Mesilla basin (Witcher et al., 2004) and two groundwater samples with elevated salinity (No. 75-76) collected by Szynkiewicz et al. (Part 1 - this 
volume) in Bosque del Apache, central New Mexico. In many cases, however, the saline and geothermal water samples plotted outside the positive trend of $\mathrm{SO}_{4}$ versus $\mathrm{Cl}$ and $\mathrm{HCO}_{3}$ (Fig. 3AB).

The $\mathrm{NO}_{3}$ concentrations of the Rio Grande samples usually varied over a range of $<1$ to $4 \mathrm{mg} / \mathrm{L}$ (Suppl. Tab. 1; Fig. 4A). However, important increases were observed locally in the Rio Grande at Vado, New Mexico (Loc. 18; 27 to 46 mg/L) in November and December of 2010 (Fig. 4A) when there was constant stream flow present between Las Cruces and Vado, New Mexico. Conversely, in January and February of 2011 the $\mathrm{NO}_{3}$ concentrations decreased to $<1 \mathrm{mg} / \mathrm{L}$ in Vado (Fig. 4A) when the Rio Grande channel was mostly dry and only localized pools of ponding water were present along the river banks. The agricultural drains south of El Paso, Texas showed considerably higher $\mathrm{NO}_{3}$ concentrations (4 to 13 $\mathrm{mg} / \mathrm{L}$ ) compared to the drains north of El Paso in the Mesilla basin ( $<1$ to $2 \mathrm{mg} / \mathrm{L}$ ) (Fig. 4B).

In most of the investigated locations, the concentrations of $\mathrm{PO}_{4}$ were very low $(<0.50 \mathrm{mg} / \mathrm{L}$ ) (Suppl. Tab. 1). However, in some months the Rio Grande water showed slightly higher $\mathrm{PO}_{4}$ concentrations in Vado, New Mexico (1.05 mg/L) and Canutillo (1.46 mg/L), and in El Paso, Texas (1.40 mg/L). Higher $\mathrm{PO}_{4}$ concentrations were usually observed in the agricultural drains south of El Paso, Texas (0.15-1.77 $\mathrm{mg} / \mathrm{L}$ ) compared to the drains in Mesilla basin (0.06 to $0.45 \mathrm{mg} / \mathrm{L}$ ) (Suppl. Tab. 1).

The $\mathrm{NO}_{3}$ and $\mathrm{PO}_{4}$ concentrations of the waste water effluent samples varied from $\sim 10-50 \mathrm{mg} / \mathrm{L}$ and 1-6 mg/L, respectively, except for the waste effluent in Las Cruces, New Mexico (Loc. 57), which contained $\sim 100 \mathrm{mg} / \mathrm{L}$ and $\sim 16 \mathrm{mg} / \mathrm{L}$ of $\mathrm{NO}_{3}$ and $\mathrm{PO}_{4}$ on the date of our sampling, respectively (Suppl. Tab. 1).

\section{2. $\mathrm{N}$ and $\mathrm{O}$ isotope compositions of $\mathrm{NO}_{3}$}

Randomly selected samples of the Rio Grande water (2009-2010), showed wide $\delta^{15} \mathrm{~N}$ and $\delta^{18} \mathrm{O}$ variations with the lowest values upstream at Truth or Consequences (No. 77; $+8.1 \%$ and $-4.7 \%$, respectively) compared to higher values downstream at west El Paso (No. 20; +16.4 to $+42.6 \%$ and +5.9 to $+19.0 \%$, respectively). The $\delta^{15} \mathrm{~N}$ of agricultural drains south of El Paso (Locs. 53, 54) ranged from +17.5 to +24.2 $\%$ and $\delta^{18} \mathrm{O}$ from +5.4 to $+8.7 \%$ (Fig. $4 \mathrm{C}$ ).

\section{3. $\mathrm{S}$ and $\mathrm{O}$ isotope compositions of $\mathrm{SO}_{4}$}

The $\delta^{34} \mathrm{~S}$ of $\mathrm{SO}_{4}$ in the Rio Grande varied over a narrow range, from -0.6 to $+2.5 \%$ (Fig. $5 \mathrm{~A}$ ). Only in west El Paso, Texas (Loc. 20) did the $\delta^{34} \mathrm{~S}$ show a distinctive increase from +1.4 to $+5.0 \%$ in the nonirrigation seasons. The $\delta^{18} \mathrm{O}$ of $\mathrm{SO}_{4}$ in the Rio Grande varied from +4.6 to $+8.1 \%$ (Fig. $5 \mathrm{~B}$ ).

The $\delta^{34} \mathrm{~S}_{\text {of }} \mathrm{SO}_{4}$ in drains in the Mesilla basin (Loc. 46-51) varied over a greater range, from -0.7 to $+5.1 \%$, compared to the agricultural drains south of El Paso (Loc. 53-54), from +1.2 to $+2.8 \%$ o (Fig. 6A). The Montoya Drain in west El Paso, Texas, (Loc. 49) showed the highest $\delta^{34} \mathrm{~S},+6.1$ to $+7.2 \%$ (Fig. 
$6 \mathrm{~A})$. Conversely, the $\delta^{18} \mathrm{O}$ of $\mathrm{SO}_{4}$ in drains varied over a narrower range, from +5.0 to $+8.1 \%$, with slight increases in the Montoya drain, from +8.0 to $+9.4 \%$ (Figs. 6B).

The $\delta^{34} \mathrm{~S}$ of $\mathrm{SO}_{4}$ in the saline groundwater endmembers varied from +7.9 to $+10.5 \%$ (Fig. 7), while the $\delta^{34} \mathrm{~S}$ of the waste effluents in the studied cities varied from +3.8 to $+7.1 \%$. The $\delta^{34} \mathrm{~S}$ of seventeen fertilizer samples varied from, -2.1 to $+13.6 \%$ (Fig. 7; Tab. 1). However, the average and median $\delta^{34} \mathrm{~S}$ were skewed toward the lighter end of this range, $+4.0 \%$ and $+2.8 \%$, respectively.

The $\delta^{18} \mathrm{O}$ of groundwater $\mathrm{SO}_{4}$ varied over a much wider range, from +3.5 to $+11.2 \%$, with the lowest values in geothermal water at Truth or Consequences, New Mexico (Loc. 77) (Fig. 7). In contrast, the $\delta^{18} \mathrm{O}$ of waste effluent $\mathrm{SO}_{4}$ varied over a smaller range $\left(+2.2\right.$ to $+3.0 \%$ (Fig. 7). The $\delta^{18} \mathrm{O}$ of fertilizers had relatively high values of +8.3 to $+17.1 \%$, with average and median values of $+12.5 \%$ and $+11.5 \%$ (Fig. 7; Tab. 1).

\section{Discussion}

\subsection{Shallow versus deep groundwater inflows}

Due to limited precipitation, enhanced agricultural activity, and the presence of populous urban centers in Las Cruces, New Mexico (Loc. 17), El Paso, Texas (Loc. 20), and Juárez, Mexico, large anthropogenic impacts on water availability and quality are observed in this portion of the Rio Grande (Fig. 2). Major use of the Rio Grande water in this region is for flood irrigation to grow pecans, chilies, cotton, alfalfa, and other minor crops that can tolerate elevated water salinity. In drier months (e.g., fall and winter), groundwater from the closely-connected alluvial aquifers of the Rio Grande Valley is used to supplement surface water for flood irrigation. While evapotranspiration is partly responsible for increasing salinity (e.g., Philips et al., 2003), highly-saline geothermal water and deep basinal brines are locally important and have been previously proposed as major salinity sources to the semi-arid portion of the Rio Grande (Hogan et al. 2007; Hibbs et al. 2008). In following chapters, using new chemical and isotope results we discuss various salinity sources related to shallow and deep water flows and how they influence increasing salinity of the Rio Grande.

\subsubsection{Evidence from major water chemistry}

In addition to collecting water samples from the Rio Grande, we identified and collected samples from several salt-rich groundwater localities in order to characterize the end member geochemistries of these potential salt loading sources. Direct inflow of geothermal water to the Rio Grande, with high $\mathrm{Cl}$ and $\mathrm{Na}$ concentrations ( $\sim 1870 \mathrm{mg} / \mathrm{L}$ and $\sim 870 \mathrm{mg} / \mathrm{L}$, respectively), occurs in Truth or Consequences (Loc. 77; Fig. 2), including from small spa resorts that use these waters (Szynkiewicz et al., 2011). 
Additionally, groundwater may impact the Rio Grande in the Mesilla Valley as a result of pumping from domestic/agricultural wells in the Mesilla basin (Loc. 78-82). Saline groundwater lenses are also present at depths of $\sim 30$ to $200 \mathrm{~m}$ in the agricultural district near Fabens, Texas (Loc. 86-88). Finally, the brackish Hueco Bolson aquifer underlies much of eastern El Paso (Loc. 85) and Juarez, Mexico.

In most cases, the studied saline end members in Locations 75 through 82 and 85 through 87 (Fig. 2) showed different chemical compositions than the Rio Grande and plotted outside the major mixing trend observed for the $\mathrm{SO}_{4}$ versus $\mathrm{Cl}$ and $\mathrm{HCO}_{3}$ for the Rio Grande and associated drains and waste effluents (Fig. 3). This implies that the contributions of salts from the saline end member groundwater compositions to the Rio Grande study area were negligible. For instance, geothermal and brackish water had high $\mathrm{Cl}$ concentrations ( $\sim 500-1600 \mathrm{mg} / \mathrm{L})$ but considerably lower $\mathrm{SO}_{4}$ concentrations ( 100-600 $\mathrm{mg} / \mathrm{L})$. In contrast, the saline lenses at Fabens had high $\mathrm{SO}_{4}$ concentrations ( $\left.600-4700 \mathrm{mg} / \mathrm{L}\right)$ but low $\mathrm{Cl}$ concentrations ( 200 mg/L); except for the deepest packet of saline water (200 m) which showed very high $\mathrm{Cl}$ concentrations $(9373 \mathrm{mg} / \mathrm{L})$ but substantially lower $\mathrm{SO}_{4}$ concentrations $(1315 \mathrm{mg} / \mathrm{L})$. Lack of direct mixing of the Rio Grande with saline end members was also observed for the relationship of $\mathrm{SO}_{4}$ versus $\mathrm{HCO}_{3}$ (Fig. 3). Our observations are consistent with recent mass balance calculations done for the Middle Rio Grande (e.g., the Socorro basin) suggesting a minor ( $5 \%)$ salinity increases due to leaking of localized brine pools originated from surface evaporation of endogenic fluids (Williams et al. 2013).

Geochemical data suggest that the surface water system, including the Rio Grande, drains, and wastewater inflows are all interrelated (Fig. 3). This is probably a result of mixing in the surface environment since the drain and city wastewaters are interconnected and flow directly into the Rio Grande. Moreover, the drains and city wastewater effluents showed higher salinity (average $2.48 \mathrm{mS} / \mathrm{cm}$ and $1.89 \mathrm{mS} / \mathrm{cm}$, respectively) compared to the Rio Grande (average $1.36 \mathrm{mS} / \mathrm{cm}$ ) (Suppl. Table 1), suggesting they are most likely important in increasing the salinity of the river.

\subsubsection{Evidence from $\mathrm{S}$ and $\mathrm{O}$ isotope composition of $\mathrm{SO}_{4}$}

The $\delta^{34} \mathrm{~S}$ and $\delta^{18} \mathrm{O}$ of dissolved $\mathrm{SO}_{4}$ help in characterizing the sources of $\mathrm{SO}_{4}$ and overall salinity in the Rio Grande. Dissolution/oxidation of bedrock sulfur (e.g., evaporites, sulfides) involves relatively small S and O isotope fractionations (<1-2 \%o; e.g., Krouse and Grinenko, 1991; Clark and Fritz, 1997; Krouse and Mayer, 2000). Therefore, the $\delta^{34} \mathrm{~S}$ of aqueous $\mathrm{SO}_{4}$, and in some cases $\delta^{18} \mathrm{O}$ (e.g., dissolution of evaporites), are good environmental tracers to study mixing processes in hydrological systems (e.g., Knöller et al., 2005; Yuan and Mayer 2012). This is particularly true for watersheds such as the Rio Grande which exhibit wide variations of isotope composition in $\mathrm{SO}_{4}$ end members (Szynkiewicz et al. Part 1, this volume). In upstream locations near the Rio Grande headwaters, the $\delta^{34} \mathrm{~S}$ and $\delta^{18} \mathrm{O}$ of the Rio Grande $\mathrm{SO}_{4}$ show relatively low values (ranges of -3.7 to $+0.7 \%$ and -2.2 to $+4.5 \%$, respectively) 
because of prevailing oxidation of the bedrock sulfides which are common in the Tertiary volcanic and Cretaceous sedimentary formations (Szynkiewicz et al. - Part 1, this volume). However, in downstream locations, such as our study area, the bedrock is dominated by Paleozoic/Mesozoic sedimentary formations (usually of marine origin) with distinctively high $\delta^{34} \mathrm{~S}$ and $\delta^{18} \mathrm{O}$ values (ranges of +8 to $+12 \%$ and +10 to $+12 \%$, respectively; Lueth et al., 2005; Moore et al., 2008; Szynkiewicz et al., 2011). Generally, the studied saline end members and groundwater of the semi-arid Rio Grande appear reflective of dissolution of local sedimentary rocks, with high $\delta^{34} \mathrm{~S}$ and $\delta^{18} \mathrm{O}(+7.9$ to $+10.5 \%$ and +6.8 to $+11.2 \%$, respectively; Fig. 7 and Szynkiewicz et al. Part $1-$ this volume). The geothermal water at Truth or Consequences (Loc. 77) had an anomalously low $\delta^{18} \mathrm{O}$ of $+3.5 \%$ compared to high $\delta^{34} \mathrm{~S}$ of $+9.1 \%$ (Fig. 7), which probably resulted from high-temperature oxygen exchange between $\mathrm{SO}_{4}$ and water (Szynkiewicz et al. Part 1 - this volume).

The water from the Rio Grande and agricultural drains of the Mesilla and Hueco-Bolson basins showed considerably lower $\delta^{34} \mathrm{~S}(-0.6$ to $+2.5 \%)$ and $\delta^{18} \mathrm{O}(+4.4$ to $+6.9 \%$ o than the possible groundwater endmembers (Fig. 7, 8). As with the major ion chemistry of the Rio Grande (described in Chapter 5.1.1; Fig. 3), the differences in $\delta^{34} \mathrm{~S}$ and $\delta^{18} \mathrm{O}$ isotope distributions suggest negligible inputs of sedimentary $\mathrm{SO}_{4}$ from groundwater sources into the Rio Grande. Moreover, the seasonal variations of $\delta^{34} \mathrm{~S}$ and $\delta^{18} \mathrm{O}$ for the Rio Grande and the drains were relatively small in 2010 and 2011 (Fig. 5, 6). Generally, the isotopic signatures of the Rio Grande and its drains were similar to the upstream Elephant Butte and Caballo reservoirs $\left(\delta^{34} \mathrm{~S}+0.6\right.$ to $+1.3 \%$ o, $\delta^{18} \mathrm{O}+3.2$ to $+5.5 \%$ ) (Fig. 8), a major source of irrigation water for agriculture in the Las Cruces and El Paso areas (Locs. 16-19, 53-54).

Nevertheless, some important localized contributions of sedimentary $\mathrm{SO}_{4}$ were observed in the drains of west El Paso (Loc. 47-50) because their $\delta^{34} \mathrm{~S}$ and $\delta^{18} \mathrm{O}$ were usually higher $(+2.2$ to $+7.2 \%$ and +6.0 to $+9.4 \%$, respectively) compared to the Rio Grande and agricultural drains (Fig. 5AB, 6AB). We suggest that this might have resulted from both the watering of west El Paso (e.g., irrigation for urban landscapes and golf fields) with municipal aquifer water, carrying the $\mathrm{SO}_{4}$ with higher $\delta^{34} \mathrm{~S}$ and $\delta^{18} \mathrm{O}$ from dissolution of local sedimentary rocks enriched in Paleozoic/Mesozoic gypsum and anhydrite of marine origin, and further interaction of this water with the sedimentary bedrock.

Additionally, in west El Paso (Loc. 20) some agricultural drains intersect the groundwater table of natural salt flats (Fig. 2). Salt flats are low-elevation sites covered with various evaporative minerals (e.g., sulfates, chlorides, carbonates). They are attributed to an elevated saline groundwater (e.g., brine) that is continuously evaporating as it approaches the ground surface. This type of settings is common in the Rio Grande rift because of high surface temperatures and the closed-drainage structures of many of the topographic basins (e.g., Langford, 2003). The source of water in salt flats is surface and groundwater recharge from surrounding mountain ranges and upwelling groundwater at the basin terminus. The 
shallow groundwater of the salt flat in west El Paso is characterized by high $\delta^{34} \mathrm{~S}$ of $+12.4 \%$ (Moore et al. 2008) which suggests major $\mathrm{SO}_{4}$ sources from dissolution of local sedimentary rocks. The $\delta^{34} \mathrm{~S}$ alone cannot be used for distinguishing between deep and shallow groundwater flows in this area because similar sedimentary strata crop out at the surface and are buried in the basin center. Nevertheless, this salt flat is intersected by the Montoya drain (Loc. 50), which conveys water from the upstream irrigation district (Newmexas drain at Loc. 48) and the storm/residential drains of west El Paso (Loc. 49). Because of high groundwater salinity in the salt flat (e.g., $\mathrm{SO}_{4} \sim 5100-6200 \mathrm{mg} / \mathrm{L}, \mathrm{Cl} \sim 7900-18000 \mathrm{mg} / \mathrm{L}$; Moore et al. 2008), the Montoya Drain had the highest $\mathrm{SO}_{4}$ and $\mathrm{Cl}$ concentrations (700 to $1600 \mathrm{mg} / \mathrm{L}$ and 600 to $1750 \mathrm{mg} / \mathrm{L}$, respectively) and $\delta^{34} \mathrm{~S}(+6.1$ to $+7.0 \%$ ) among the studied drains (Fig. 6). Consequently, the concentrations of major ions usually increased in the Rio Grande below the confluence with Montoya drain (Location 20, Fig. 5CD) and were followed by important increases of $\delta^{34} \mathrm{~S}$ (Fig. 5A), particularly during the non-irrigation season $(+2$ to $+5 \%$ ) when the stream flows were reduced and less water was available in the Rio Grande for dilution. Using the changes of $\delta^{34} S$ between Canutillo (Loc. 19) and west El Paso (Loc. 20), S isotope mass balance calculations suggest that in the dry fall/winter seasons the Montoya drain $\left(\delta^{34} \mathrm{~S} \sim+7 \%\right.$ ) may contribute up to $\sim 60 \%$ of $\mathrm{SO}_{4}$ (derived from the evaporative brine of the salt flat) to the Rio Grande in west El Paso. This contribution is reduced to only $\sim 20 \%$ in the irrigation season when stream flows greatly increase due to water releases from the upstream reservoirs.

\subsubsection{Comparison of $\mathrm{SO}_{4}$ fluxes from evaporative brine versus irrigation runoff}

In order to compare the $\mathrm{SO}_{4}$ fluxes between the surface evaporative brine such as that observed in west El Paso (Loc. 20) and the typical irrigation runoff, we also calculated seasonal $\mathrm{SO}_{4}$ fluxes of the Tornillo drain south of El Paso (Loc. 54 on Fig. 2) between 2009 and 2011. The Tornillo drain had the highest $\mathrm{SO}_{4}$ concentrations (608 to $717 \mathrm{mg} / \mathrm{L}$ ) among the studied agricultural drains (Fig. 6C). The Tornillo drain, however, does not show any surface evidence of natural salt flats in the nearby area. The relatively low $\delta^{34} \mathrm{~S}$ of the Tornillo drain and its small seasonal variation $(+2.2$ to $+2.8 \%$ ) also suggests that evaporite-derived $\mathrm{SO}_{4}$ is negligible (Fig. 6A). Generally, the $\mathrm{SO}_{4}$ fluxes of the Tornillo drain varied over the narrow range of 62 to 89 metric tons/day between 2009 and 2011 (Fig. 9). In contrast, the Rio Grande in west El Paso at Location 20 showed much wider seasonal variations of $\mathrm{SO}_{4}$ fluxes (Fig. 9). Considerably higher $\mathrm{SO}_{4}$ fluxes were observed during irrigation ( 200 to 450 metric tons/day) compared to smaller fluxes in the fall/winter ( $\sim 30$ to 80 metric tons/day) when the stream flows were reduced but the inflow from the evaporative brine (salt flat) via the Montoya drain was the highest. Using the estimated $\mathrm{SO}_{4}$ contributions from $\mathrm{S}$ isotope mass balance (20 to $60 \%$; see chapter 5.1.2), we calculated that the $\mathrm{SO}_{4}$ flux from the Montoya drain accounted for at least $\sim 18-48$ metric tons/day of $\mathrm{SO}_{4}$ during the non-irrigation and $\sim 40-90$ metric tons/day during the irrigation season. Therefore, the amount of $\mathrm{SO}_{4}$ 
loading to the Rio Grande via the Montoya drain is $\sim 35 \%$ less than the $\mathrm{SO}_{4}$ flux attributable to the Tornillo drain. However, the size of the salt flat intersected by Montoya drain is considerably smaller $(\sim 2$ $\left.\mathrm{km}^{2}\right)$ compared to the Tornillo drainage area $\left(\sim 190 \mathrm{~km}^{2}\right)$. Therefore, we infer that (at least in one case identified here) poorly-designed agricultural drains intersecting the water table of localized evaporative brines are important contributors of salts to the Rio Grande.

\subsubsection{Evidence from $U$ isotopes}

In order to better distinguish between shallow and deeper groundwater sources (upwelling) in the studied stretch of the Rio Grande, we also measured the $\left({ }^{234} \mathrm{U} /{ }^{238} \mathrm{U}\right)$ activity ratios for the water samples collected in November 2009 and April 2010. Generally, groundwater that has experienced a deeper circulation history can be distinguished from surface water by higher $\left({ }^{234} U /{ }^{238} U\right.$ ) ratios (Kronfeld, 1974; Kronfeld et al., 1994; Chabaux et al., 2003). This is due to precipitation of small amounts of $U$ from water when groundwater moves through a redox front in the aquifer (Langmuir, 1978; Drever, 1997) and enhanced transfer of alpha-recoil ${ }^{234} \mathrm{U}$ from the U-rich aquifer rock surfaces back to the U-depleted groundwater (Kronfeld et al., 1974; 1994). Accordingly, in our study the deeper saline end members from Truth or Consequences had a higher $\left({ }^{234} \mathrm{U} /{ }^{238} \mathrm{U}\right)$ ratio of 2.65, as did the saline groundwater from Fabens $\left({ }^{234} \mathrm{U} /{ }^{238} \mathrm{U}\right.$ of 2.54$)$ (Fig. 10). In contrast, the ${ }^{234} \mathrm{U} /{ }^{238} \mathrm{U}$ ratios were considerably lower in the Montoya drain intersecting the evaporative brine of the salt flat $(\sim 1.55)$, the Rio Grande ( 1.62 to 1.88$)$, the Tornillo agricultural drain ( 1.35), and fertilizers ( 1.00) (Fig. 10). This suggests that the most important salt sources influencing the Rio Grande in the study area are from shallow water circulation as opposed to deep inflows of saline fluids. The small increases of the ${ }^{234} \mathrm{U} /{ }^{238} \mathrm{U}$ ratios, up to 2.13 and 2.06 , were only observed in the Rio Grande at Truth or Consequences (Loc. 77) and at Canutillo (Loc. 19), respectively, during the non-irrigation season of 2009 (Fig. 10). Because the $\delta^{34} \mathrm{~S}$ also importantly increased ( $+4.2 \%$ ) in Truth or Consequences, we attribute the increasing $\left({ }^{234} \mathrm{U} /{ }^{238} \mathrm{U}\right)$ ratios to the direct inflow of geothermal water $\left(\delta^{34} \mathrm{~S}+9.1 \%\right)$ to the Rio Grande from the spa resorts which are common in this area. However, at Canutillo the $\delta^{34} \mathrm{~S}$ was considerably lower $(+2.7 \%$ ) compared to the regional groundwater $(>+8 \%$; Szynkiewicz et al. 2011). In this area, aquifer groundwater is often used to support irrigation with the Rio Grande surface water. Therefore, the subsequent lowering of $\delta^{34} \mathrm{~S}$ of the aquifer groundwater is caused by mixing with low $\delta^{34} S$ of the Rio Grande water. Given that the Rio Grande at Canutillo (Loc. 19) completely dries out during the non-irrigation season, we suggest that the increasing ${ }^{234} \mathrm{U} /{ }^{238} \mathrm{U}$ activity ratios in this location are mainly controlled by shallow irrigation return flows which represent a portion of the aquifer groundwater pumped for agricultural activity. Considerable inflow of deep groundwater would be accompanied by higher increases of $\delta^{34} \mathrm{~S}$, but this scenario does not fit the data. 


\subsection{Additional indication of the importance of surface processes}

\subsubsection{Agricultural impact on $\mathrm{SO}_{4}$ cycling and microbial processes}

Although the $\mathrm{SO}_{4}$ concentrations considerably increased in the study area with the downstream flow in the Rio Grande and agricultural drains (Fig. 8), they were not accompanied by important increases of $\delta^{34} \mathrm{~S}$ which varied over a narrow range of +0.6 to $+2.5 \%$ (Fig. 5A, 8A). The one exception was in west El Paso (Loc. 20) for which the increasing $\delta^{34} \mathrm{~S}$ of the Rio Grande (Fig. 5A) resulted from surface inflow of evaporative brine via the Montoya drain which intersects groundwater table of natural salt flat (See chapter 5.1.2). In contrast, the $\delta^{18} \mathrm{O}$ of $\mathrm{SO}_{4}$ showed larger increases versus $\mathrm{SO}_{4}$ concentrations and relative to the distance from the Rio Grande headwaters (from -2.2 to $+7.1 \%$ ) and from the Elephant Butte and Caballo reservoirs (form +3.2 to $+7.1 \%$ ) (Fig. 7, 8B). Moreover, on the plot of $\delta^{34} \mathrm{~S}$ versus $\delta^{18} \mathrm{O}$ the studied water samples were usually concentrated toward higher $\delta^{18} \mathrm{O}$ values and above both 1) the regression line defining mixing trend of sulfide- and evaporite-derived $\mathrm{SO}_{4}$ and 2) the hypothetical mixing line considering addition of low-temperature evaporite-derived $\mathrm{SO}_{4}$ to the Rio Grande surface water (Fig.7). We suggest that this is indicative of additional $\mathrm{SO}_{4}$ inputs with distinctive high $\delta^{18} \mathrm{O}$ values into the studied water samples. Previous investigators have shown the importance of $\mathrm{SO}_{4}$ contributions from the application of fertilizers in the areas affected by agriculture (Mizota and Sasaki, 1996; Moncaster et al., 2000; Mallén, 2000; Victòria et al., 2004; Brenot et al., 2007). In the Rio Grande watershed, the S-rich fertilizers such as ammonium sulfate, elemental sulfur, and sulfuric acid are commonly applied to agricultural fields to manage salinity hazards. Except for one sample of ammonium sulfate with higher $\delta^{34} \mathrm{~S}$ and $\delta^{18} \mathrm{O}\left(+10.1\right.$ and $+8.3 \%$ ), these fertilizers showed relatively low $\delta^{34} \mathrm{~S}$ of -2.1 to $+4.8 \%$ and high $\delta^{18} \mathrm{O}$ of +9.1 to $+16.8 \%$ (Fig. 7 ; Tab. 1). Therefore, the addition of fertilizers in this stretch of the Rio Grande might account for the increase in $\delta^{18} \mathrm{O}$ with very little influence on the $\delta^{34} \mathrm{~S}$ as a function of increasing $\mathrm{SO}_{4}$ concentrations (Fig. 8). Other less-soluble fertilizers such as soil amendments gypsum had higher $\delta^{34} \mathrm{~S}$ of +5.1 to $+13.6 \%$ in addition to high $\delta^{18} \mathrm{O}$ (Tab. 1), thus, they could not be distinguished from dissolution of bedrock evaporites with gypsum and anhydrite with similar high $\delta^{34} \mathrm{~S}$ of +8 to $+12 \%$ (Lueth et al., 2005; Moore et al., 2008; Szynkiewicz et al., 2011).

The $\delta^{18} \mathrm{O}$ of $\mathrm{SO}_{4}$ of the Rio Grande and drains in the study area was usually higher $(+4.4$ to $+6.9 \%$ ) than the $\delta^{18} \mathrm{O}$ of the Rio Grande in the Elephant Butte and Caballo reservoirs ( +3.2 to $+4.0 \%$ ) but it was lower compared to fertilizers $(+8.3$ to $+16.8 \%$ ) and low-temperature aquifer water $(+6.8$ to $+11.2 \%$ ) (Fig. 7, 8). This implies that in addition to mixing between different $\mathrm{SO}_{4}$ end members (e.g., evaporites, fertilizers) another mechanism may be causing a lowering of $\delta^{18} \mathrm{O}$ in the studied area. Since up to 70-90 $\%$ of the Rio Grande water undergoes infiltration through agricultural soils during irrigation (Ellis et al., 1993), some lowering of $\delta^{18} \mathrm{O}$ might be more controlled by microbial processes in soils (e.g., Mayer et al., 
1995; Shanley et al., 2005; Yuan and Mayer, 2012). Assimilatory microbial $\mathrm{SO}_{4}$ reduction and reoxidation in soils usually lead to lowering of initial $\delta^{18} \mathrm{O}$ in $\mathrm{SO}_{4}$ because some oxygen atoms in the $\mathrm{SO}_{4}$ are replaced by oxygen from soil water with negative $\delta^{18} \mathrm{O}$. These processes typically have only a small effect on the $\delta^{34} \mathrm{~S}$ values of $\mathrm{SO}_{4}$ unless dissimilatory bacterial sulfate reduction occurs (Mitchel et al., 1998). The latter causes substantial increases of $\delta^{34} \mathrm{~S}$ followed by a decrease of $\mathrm{SO}_{4}$ concentration in aqueous environment (e.g., Canfield, 2001). Because the $\delta^{34} \mathrm{~S}$ of the Rio Grande did not change much despite increasing $\mathrm{SO}_{4}$ concentrations (100 to $750 \mathrm{mg} / \mathrm{L}$ ) (Fig. 8), it is clear that dissimilatory microbial $\mathrm{SO}_{4}$ reduction had a negligible impact on the isotope composition of the Rio Grande $\mathrm{SO}_{4}$. Generally, the observed lowering of $\delta^{18} \mathrm{O}$ in Rio Grande and drains is in a good agreement with similar pattern observed by Yuan and Mayer (2012) in the adjacent watershed of the Pecos River in eastern New Mexico. They reported that up to $63 \%$ of dissolved $\mathrm{SO}_{4}$ in the Pecos River has been recycled in the irrigated soils causing the $\delta^{18} \mathrm{O}$ decreases by $5 \%$.

An alternate or perhaps additional mechanism of lowering of $\delta^{18} \mathrm{O}$ could be inflows of $\mathrm{SO}_{4}$ from waste effluents with low $\delta^{18} \mathrm{O}$ of +2.2 to $3.0 \%$ in Las Cruces and El Paso (Figs.7, 8). However, the effluent $\mathrm{SO}_{4}$ had considerably higher $\delta^{34} \mathrm{~S}$ of +3.8 to $+7.1 \%$ compared to the Rio Grande and agricultural drains $\left(-0.6\right.$ to $+2.5 \%$ ), thus, this source is inconsistent with the consistency of the $\delta^{34} \mathrm{~S}$ in the Rio Grande and drains (Figs. 6, 8). Moreover, the concentrations of $\mathrm{SO}_{4}$ were importantly higher in the studied drains ( 250 to $1500 \mathrm{mg} / \mathrm{L})$ compared to waste effluents $(\sim 120$ to $530 \mathrm{mg} / \mathrm{L})$ that we attribute to increased evaporation during flood irrigation. This, in turn, indicates that the inflows of drain $\mathrm{SO}_{4}$ are more important in the Rio Grande compared to municipal sources as inferred using S and O isotope data alone.

\subsubsection{Anthropogenic $\mathrm{NO}_{3}$ contributions}

Prevailing shallow recharge to the Rio Grande is also inferred from the elevated $\mathrm{NO}_{3}$ concentrations along the Mesilla basin, from $<1$ to $46 \mathrm{mg} / \mathrm{L}$ (Fig. 4A). The measurements of $\delta^{15} \mathrm{~N}$ and $\delta^{18} \mathrm{O}$ in $\mathrm{NO}_{3}$ on the Rio Grande water samples in Truth or Consequences (Loc. 77) and west El Paso (Loc. 20) were consistent with the variation of $\delta^{15} \mathrm{~N}$ and $\delta^{18} \mathrm{O}$ reported for manure and septic tanks undergoing denitrification (Fig. 4C; e.g., Kendall 1998). The highest $\mathrm{NO}_{3}$ concentrations (27 to $46 \mathrm{mg} / \mathrm{L}$ ) were observed during fall 2010 in Vado (Loc. 18), located $\sim 25 \mathrm{~km}$ downstream from the waste water treatment plant in Las Cruces (Loc. 57) (Fig. 4A). This plant showed considerably higher $\mathrm{NO}_{3}$ (90 to $110 \mathrm{mg} / \mathrm{L}$ ) compared to other plants in west El Paso (22-46 mg/L; Suppl. Table 1). In Vado, however, the $\mathrm{NO}_{3}$ concentrations substantially decreased to $<1 \mathrm{mg} / \mathrm{L}$ closer to the end of non-irrigation season (Fig. 4A). Most likely, this was due to changing hydrological conditions. In January and February of 2011 there was no continuous surface water flow in the Rio Grande between Las Cruces and Vado. Instead, only localized ponded water was present in the Rio Grande channel. Consequently, our results (Fig. 4A) 
suggest that particularly during the winter there is important infiltration of the Las Cruces waste effluent into the Rio Grande alluvial aquifer system.

Alternatively, in Vado the elevated $\mathrm{NO}_{3}$ contributions might be sourced by runoff from several dairy farms located 2-3 km east from the Rio Grande. Nevertheless, our sampling point in Vado (Loc. 18) was located upstream from the dairy farms. Therefore, the observed increases of $\mathrm{NO}_{3}$ in the Rio Grande during fall 2010 at Vado (Fig. 4A) had to be mainly controlled by municipal waste water from Las Cruces since this was the largest measured contributor of $\mathrm{NO}_{3}$ in the nearby area. In Vado, the waste water $\mathrm{NO}_{3}$ contributions to the Rio Grande became proportionally higher in the fall because of the decreased flows related to the reduced releases of surface water from upstream reservoirs.

Generally, the $\mathrm{NO}_{3}$ and $\mathrm{PO}_{4}$ concentrations of the studied drains were considerably lower $(<1$ to 3 $\mathrm{mg} / \mathrm{L}$ and 0.06 to $0.45 \mathrm{mg} / \mathrm{L}$, respectively) compared to the waste effluents (22 to $110 \mathrm{mg} / \mathrm{L}$ and 1 to 16 mg/L, respectively) (Fig. 4B), suggesting smaller $\mathrm{NO}_{3}$ and $\mathrm{PO}_{4}$ contributions from agricultural sources to the Rio Grande in the Mesilla basin. It is noteworthy that the agricultural drains south of El Paso in the Hueco-Bolson basin (Loc. 53-54, Fig. 2) had considerably higher $\mathrm{NO}_{3}$ and $\mathrm{PO}_{4}$ concentrations (4 to 13 $\mathrm{mg} / \mathrm{L}$ and 0.2 to $2 \mathrm{mg} / \mathrm{L}$, respectively) compared to the Mesilla's drains. While application of different fertilizers enriched in nitrogen and phosphorous might be locally important, the increasing effluent inflows into the irrigation canals from three waste treatment plants in El Paso might also be influencing higher $\mathrm{NO}_{3}$ and $\mathrm{PO}_{4}$ loadings in the studied drains at Locations 53 and 54. Because of prevailing dry conditions, particularly in this area, the waste effluents represent a large fraction of the stream flow in the irrigation canals. Therefore, urban sources (e.g., waste effluents) are likely important in increasing $\mathrm{NO}_{3}$ and $\mathrm{PO}_{4}$ loadings in the irrigation water used in downstream locations south of El Paso. The latter is supported by the measured $\delta^{15} \mathrm{~N}$ and $\delta^{18} \mathrm{O}$ of $\mathrm{NO}_{3}$ in the drains at Locations 53 and 54 which were within the range observed for the Rio Grande and the septic waste end member (Fig. 4C). Since the waste effluent from Juarez, Mexico discharges to the Rio Grande $160 \mathrm{~km}$ south of El Paso, we did not consider it as important in increasing $\mathrm{NO}_{3}$ and $\mathrm{PO}_{4}$ loads in the studied drains at Locations 53 and 54 situated closer to El Paso $(\sim 50 \mathrm{~km})$. Additionally, the U.S. and Mexican irrigation canals and drains are not connected with each other, thus, they can be treated separately in this interpretation.

\subsection{Evaporation and evolution of water chemistry}

Irrigation water applied to agricultural fields is consumed by crops (transpires or becomes plant biomass), infiltrates to groundwater aquifer, and evaporates from the surface and/or the near-surface soil. The evaporative loss is particularly important in arid zones because of high annual surface temperatures and low air humidity (e.g., Sheta et al., 2006; van der Akker et al., 2011; Jafari et al., 2012). Additionally, 
ponding of water and evaporation in topographic depressions is important in increasing surface salt accumulation (Acosta et al., 2011; van den Akker et al., 2011).

In the Rio Grande study area, the water losses due to evapotranspiration may reach up to $70 \%$ (Phillips et al. 2003). Majority of the irrigated lands in the studied area have fine-textured, smectitic, clay soils that have low permeability (e.g., Ganjegunte et al. 2011). This means that infiltration rates are slow and there is more time for the irrigation water to evaporate. Therefore, evapotranspiration is likely a primary driver in increasing the concentrations of salts in this region of the Rio Grande. Since evapotranspiration does not considerably fractionate $\mathrm{S}$ isotopes, the $\mathrm{SO}_{4}$ and $\mathrm{Cl}$ concentrations of the Rio Grande were able to greatly increase (Fig. 5C,D), while at the same time the changes in $\delta^{34} \mathrm{~S}$ were small (Fig. 5A).

Salt mobility related to changes of seasonal conditions (e.g., irrigation, rainfall, evaporation) have been recognized as important for salt loads and storage in arid zones (Yaun and Miyamoto, 2005, 2008; Yuan et al., 2007; Acosta et al. 2011). For example, secondary salts such as carbonates $\left(\mathrm{CaCO}_{3}\right)$, sulfates (gypsum $\mathrm{CaSO}_{4} \cdot 2 \mathrm{H}_{2} \mathrm{O}$, thenardite $\mathrm{Na}_{2} \mathrm{SO}_{4}$ ) and chlorides (halite $\mathrm{NaCl}$ ) are commonly found in arid soils (e.g., Sheta et al., 2000; Graham and O'Geen 2010; Jafari et al., 2012). The formation of these salts is mainly controlled by mineral solubility (Sheta et al., 2000; Jafari et al., 2012) and environmental conditions via changes of the evaporation and dilution rates (Mees, 2003). Less soluble calcite precipitates first compared to the more soluble gypsum (followed by other phases like thenardite and halite which precipitate later from more concentrated solutions in evaporative brine pools).

In our study area, the formation of secondary calcite commonly occurs in the shallow subsurface of agricultural soils (6-10 wt. \%; Cox, 2012) and substantially decreases the soil permeability of the irrigated land. For this reason sulfuric acid with low $\delta^{34} \mathrm{~S}$ and high $\delta^{18} \mathrm{O}$ (Tab. 1) is sometimes used by farmers to lower the $\mathrm{pH}$ of irrigation water and dissolve secondary calcite. Consequently, all of the analyzed Rio Grande and drain water samples were usually saturated (or supersaturated) with respect to calcite (SI: 0 to +1 ) (Fig. 11). However, the water samples were undersaturated with respect to gypsum (SI: -1 to 0 ), and greatly undersaturated with respect to halite (SI: -8 to -6 ) and thenardite (SI: -10 to -8 ). We suggest that the evolution of water chemistry toward $\mathrm{Na}_{-} \mathrm{SO}_{4}-\mathrm{Cl}$ in the Rio Grande watershed is attributable to the fact that calcite is precipitating in the system. This is supported by higher concentrations of $\mathrm{SO}_{4}, \mathrm{Cl}$, and $\mathrm{Na}$ ( $500-750 \mathrm{mg} / \mathrm{L}, 300-900 \mathrm{mg} / \mathrm{L}$, and 100-600 mg/L, respectively) compared to lower (and relatively consistent) concentrations of $\mathrm{Ca}$ and $\mathrm{HCO}_{3}(\sim 60-200 \mathrm{mg} / \mathrm{L}$ and $200-250 \mathrm{mg} / \mathrm{L}$, respectively) in the studied Rio Grande and drain water samples (see the deviation from the evaporation trend in Fig. 3B). Most likely, the observed salinization effect is intensified by flood irrigation which exposes more water to evaporative concentration and subsequent salt accumulation (e.g., calcite) in the shallow soil zone of irrigated land. 


\section{Summary}

\subsection{Major conclusions}

The chemical and isotope data for the semi-arid reach of the Rio Grande watershed investigated in our study indicate that surface processes lead to the main increases of $\mathrm{SO}_{4}$ and overall salinity in the studied area of the Rio Grande. Natural inflows of saline groundwater to the Rio Grande and drains appeared to be negligible in the investigated seasons. The important inflows of highly saline water to the Rio Grande via the Montoya drain are attributable to localized surface brines forming naturally in lowelevation areas (e.g., salt flats) due to evaporation. This was recorded by considerable increases of both $\delta^{34} \mathrm{~S}$ of $\mathrm{SO}_{4}$, concentration of major ions, and lowering of the $\left.{ }^{234} \mathrm{U} /{ }^{238} \mathrm{U}\right)$ activity ratios in the Rio Grande. The application of sulfur-rich fertilizers with low $\delta^{34} \mathrm{~S}$ and high $\delta^{18} \mathrm{O}$ might be also responsible in part for additional increases of $\mathrm{SO}_{4}$ loads into the irrigation return flows and, thus, the Rio Grande. We additionally infer that during irrigation, $\mathrm{SO}_{4}$ undergoes substantial microbial recycling in the soil environment leading to decreases in $\delta^{18} \mathrm{O}$.

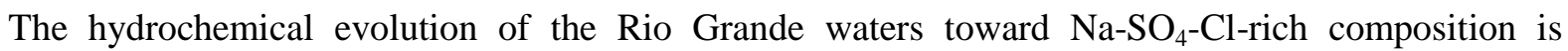
primarily caused by high evapotranspiration rates and increases in temperature leading to the precipitation of calcite. The $\mathrm{Ca}$ and $\mathrm{HCO}_{3}$ are firstly consumed by calcite precipitation because of its lower solubility compared to other salts like gypsum, thenardite and halite, thus, leaving behind water enriched in $\mathrm{Na}, \mathrm{SO}_{4}$ and $\mathrm{Cl}$. Agricultural practices during flood irrigation additionally intensify concentrative evaporation and, in turn, increase water salinity of the Rio Grande watershed.

\subsection{Synthesis and recommendations}

Increasing urban water demand coupled with expected climate changes will most likely result in the increased variability of water supply, water scarcity, and therefore the challenges of water sustainability within the context of increasing salinity in arid rivers such as the Rio Grande (Regab and Prudhomme 2002; Borrok and Engel 2014). For example, leaching of salts from agricultural soils will become increasingly important to avoid substantial salt-related crop yield loses (Jia et al., 2011; Connor et al., 2012; Rasouli et al., 2012).

In the studied portion of the semi-arid Rio Grande there is no evidence to suggest that the upwelling of saline groundwater near the river has any impact on salt loads, thus, developing management strategies to address this salt input is unpractical. Conversely, most of the salt loads appear to be attributable to near-surface processes. Therefore, reducing evaporation of irrigation water would improve efficiency of water use, leaching of salts to deeper depth within soil profile, and decrease salinization. Most likely, this could be best achieved by improved scheduling of irrigation and adoption of sub-surface drip irrigation in 
677

678

679

680

681

turfed areas (e.g., Sevostianova et al., 2011; Ganjegunte et al., 2012; Ganjegunte et al., 2013; Payero et al., 2005). Developing alternative water sources such as desalinated brackish groundwater and reclaimed municipal wastewater could conserve and extend the available freshwater resources. Mostly, the sequential and/or alternative irrigation with freshwater in the fields currently irrigated with brackish groundwater and/or marginal water (e.g., saline water, wastewater, and runoff water) could help in preventing salt buildup in shallow soil environments.

In recent years, desalination of the Rio Grande surface water has been considered by some state agencies to reduce salt loads on agricultural fields in south New Mexico and west Texas (e.g., U.S. Army Corps of Engineers). However, desalination systems are still expensive. Furthermore, the process itself generates saline waste water that would have to be disposed in the surface environment already affected by higher salt loads, unless injection of waste water to deep surface is possible. Our study shows that some of the studied drains intersect the water table of natural settings with surface brines (e.g., salt flats). Therefore, a potentially more economical approach would be re-designing the old drainage system, particularly in west El Paso, to prevent unnecessary surface inflow of highly saline water into the Rio Grande. Similar solution could be implemented in the areas where highly saline geothermal water flows directly to the Rio Grande from the spa (bath) houses (e.g., Truth or Consequences, New Mexico).

\section{Acknowledgements}

This study was supported by a State of Texas Norman Hackerman grant and NSF grant 0838120 (D. Borrok), and partially by grants from UTEP URI 14-6485-4651 (A. Szynkiewicz) and NSF EAR 1348971 (A. Szynkiewicz, L. Ma). G. Skrzypek was supported by a Future Fellowship from the Australian Research Council (FT110100352). We greatly thank to the UTEP's students Dennise Drury, Wendy De Leon, Nicole Kyger, Susan Aranda, Ana Lu Gutierrez, Ian Cappelle for the field/lab assistance and to Ben Underwood from Indiana University for assistance with sulfur isotope analysis. Phil Goodell provided assistance with chemical analysis of fertilizers by the Actlabs Life Sciences in Ancaster, Ontario, Canada. The discussions with Scott Anderholm, Malynda Cappelle, Talon Newton, Dave Love, Joel Gilbert, John Hawley, Rip Langford, Zhuping Sheng, John Sorrell, Cody Walker and the participation of first author in the Rio Grande Coalition meetings significantly helped in the planning of sampling strategy and understanding salinity challenges in the Rio Grande region. The field assistance of the El Paso Desalination Plant is also greatly appreciated.

\section{References}

Acosta, J.A., Faz, A., Jansen, B., Kalbitz, K., Martínez- Martínez, S., 2011. Assessment of salinity status in intensively cultivated soils under semiarid climate, Murcia, SE Spain. Journal of Arid Environments 75, 1056-1066.

Anderholm, S.K., 2002. Water-quality assessment of the Rio Grande Valley, Colorado, New Mexico and Texas - Surface water quality, shallow groundwater quality, and factors affecting water quality in the Rincon Valley, south-central New Mexico, 1994-95. U.S.G.S. Water-Resources Investigations Report 02-4188, pp. 125. 
Borrok, D.M., Engle, M.A., 2014. The role of climate in increasing salt loads in dryland rivers. J. Arid Environ. 111, 7-13.

Brenot, A., Carignan, J., France-Lanord, C., Benoît, M., 2007. Geological and land use control on $\delta^{34}$ S and $\delta^{18} \mathrm{O}$ of river dissolved sulfate: the Moselle river basin, France. Chem. Geol. 244, 25-41.

Canfield D. E., 2001. Biogeochemistry of sulfur isotopes. In Stable Isotope Geochemistry (eds. J.W. Valley and D.R. Cole). Mineralogical Society of America, Blacksburg, VA, vol. 43, pp. 607-636.

Casciotti, K.L., Sigman, D.M., Galanter Hastings, M., Bohlke, J.K., Hilkert, A., 2002. Measurement of the oxygen isotopic composition of nitrate in seawater and freshwater using the denitrifier method. Analytical Chemistry 74, 4905-4912.

Chabaux, F., Riotte, J., Dequincey, O., 2003. U-Th-Ra fractionation during weathering and river transport. Rev. Mineral. Geochem. 52, 533-576.

Clark, K.I., Fritz P., 1997. Environmental Isotopes in Hydrogeology. Lewis Publishers, New York, pp. 328.

Connor, J.D., Schwabe, K., King, D., Knapp, K., 2012. Irrigated agriculture and climate change: The influence of water supply variability and salinity on adaptation. Ecological Economics 77, 149-157.

Cox, C.L., 2012. Evaluation of soil sustainability along the Rio Grande in west Texas: changes in salt loading and organic nutrients due to farming practices. M.S. Thesis, University of Texas at El Paso.

Drever, J.I., 1997. The Geochemistry of Natural Waters: Surface and Groundwater Environments, |ISBN10: 0132727900.

Ellis, S.R., Levings, G.w., Carter, L.F., Richey, S.F., Radel, M.J., 1993. Rio Grande Valley, Colorado, New Mexico, and Texas. J. Amer. Wat. Res. Assoc. 29, 617-648.

Ganjegunte, G.K., Leinauer, B., Schiavon, M., Serena, M., 2013. Using Electromagnetic Induction to Determine Soil Salinity and Sodicity in Turf Root Zones. Agronomy Journal 105, 836-844.

Ganjegunte, G.K., Sheng, Z., Clark, J.A., 2012. Evaluating accuracy of soil water sensors for irrigation scheduling to conserve freshwater. Applied Water Science 2, 119-125.

Ganjegunte, G.K., Sheng, Z., Braun, R.J., 2011. Salinity management using an anionic polymer in a pecan field with calcareous-sodic soil. J. Environ. Qual. 40, 1314-1321.

Graham, R.C., O'Geen, A.T., 2010. Soil mineralogy trends in California landscape. Geoderma 154, 418437.

Gutzler, D.S., Robbins, T.O., 2010. Climate variability and projected change in the western United States: regional downscaling and drought statistics. Clim. Dyn. DOI 10.1007/s00382-010-0383-7.

Hibbs, B.J., Merino, M., 2006. A geologic sources of salinity in the Rio Grande aquifer near El Paso, Texas. New Mexico J. Sci. 44, 1-17.

Hogan, F.M., Phillips, F.M., Mills, S.K., Hendrickx, J.M.H., Ruiz, J., Chesley, J.T., Asmerom, Y., 2007. Geologic origins of salinization in semi-arid river: The role of sedimentary basin brines. Geology 35, 1063-1066.

Jafari, H., Raeisi, E., Hoehn, E., Zare, M., 2012. Hudrochemical characteristics of irrigation return flow in semi-arid regions of Iran. Hydrological Sciences Journal 57, 173-185.

Jia, Z., Luo, W., Xie, J., Pan, Y., Chen, Y., Tang, S., Liu, W., 2011. Salinity dynamics of wetland ditches receiving drainage from irrigated agricultural land in arid and semi-arid regions. Agricul. Wat. Manag. 100, 9-17.

Keller, G.R., Baldridge, W.S., 1999. The Rio Grande rift: a geological and geophysical overview. Rocky Mountain Geology 34, 121-130. 
Keller, G.R., and Cather, S.M., 1994. Introduction. In: Keller, G.R., and Cather, S.M., eds., Basins of the Rio Grande rift—structure, stratigraphy, and tectonic setting: Geological Society of America Special Paper 291, p. 1-3.

Kendall, C., 1998. Isotope tracers in catchment hydrology. C. Kendall and J.J. McDonnell (Eds.). Elsevier Science B.V., Amsterdam, pp. 519-576.

Knöller, K., Trettin, R., Strauch, G., 2005. Sulphur cycling in the drinking water catchment area of Torgau-Mockritz (Germany): insights from hydrochemical and stable isotope investigations. Hydrol. Process. 19, 3445-3465.

Kronfeld, J., Vogel, J.C., Talma, A.S., 1994. A new explanation for extreme ${ }^{234} \mathrm{U} /{ }^{238} \mathrm{U}$ disequilibria in a dolomitic aquifer. Earth Planet Sci Lett 123, 81-93.

Kronfeld, J., 1974. Uranium deposition and Th-234 alpha-recoil: an explanation for extreme ${ }^{234} \mathrm{U} /{ }^{238} \mathrm{U}$ fractionation within the Trinity aquifer. Earth and Planetary Science Letters 21, 327-330.

Krouse, H.R., Mayer, B., 2000. Sulphur and oxygen isotopes in sulphate. In: Cook P. and Herczeg A.L. (eds.), Environmental Tracers in Subsurface Hydrology. Kluwer Academic Publishers, pp. 195-231.

Krouse, H.R., Grinenko, V.A., 1991. Stable Isotopes: Natural and Anthropogenic Sulphur in the Environment. John Willey \& Sons.

Langford, R.P., 2003. The Holocene history of the White Sands dune field and influences on eolian deflation and playa lakes. Quatern. Internat. 104, 31-39.

Langmuir, D., 1978. Uranium solution-mineral equilibria at low temperatures with applications to sedimentary ore deposits. Geochimica et Cosmochimica Acta, 42, 547-569.

Lueth, V.W., Rye, R.O., Peters, L., 2005. "Sour gas"hydrothermal jarosite: ancient to modern acid-sulfate mineralization in the southern Rio Grande Rift. Chem. Geol. 215, 339-360.

Ma, L., Chabaux, F., Pelt, E., Blaes, E., Jin, L., Brantley, S., 2010. Regolith production rates calculated with uranium-series isotopes at Susquehanna/Shale Hills Critical Zone Observatory. Earth Planet. Sci. Lett. 297 (1-2), 211-225.

Mallén, G., 2000. Isotopeanalytische characterisierung hydrodynamischer und biogeochemischer Prozesse im Uferfiltrat und landseitigen Grundwässern der Torgauer Elbtalwanne unter besonderer Berücksichtigung der Herkunft und Umwandlungen von Kohlenstoff- und Schwefelspezies. Ph.D. thesis, UFZ Report 9/2000.

Mayer, B., Fritz, P., Prietzel, J., Krouse H.R., 1995. The use of stable sulfur and oxygen isotope ratios for interpreting the mobility of sulfate in aerobic forest soils. App. Geochem. 10, 161-173.

Mees, F., 2003. Salt mineral distribution patterns in soils of the Otjomongwa pan, Namibia. Catena 54, 425-437.

Mitchell, M.J., Krouse, H.R., Mayer, B., Stam, A.C., Zhang, Y., 1998. Use of stable isotopes in evaluating sulfur biogeochemistry of forest ecosystems. In: Kendall C. and McDonnell J.J. (eds.), in Catchment Hydrology. Elsevier, Amsterdam, pp. 489-518.

Mizota, C., Sasaki, A., 1996. Sulfur isotope composition of soils and fertilizers: differences between Northern and Southern hemispheres. Geoderma 71, 77-93.

Moncaster, S.J., Bottrell, S.H., Tellam, J.H., Lloyd, J.W., Konhauser, K.O., 2000. Migration and attenuation of agrochemical pollutants: insights from isotopic analysis of groundwater sulfate. Contam. Hydrol. 43, 147-163.

Moore, S.J., Bassett, R.L., Liu, B., Wolf, C.P., Doremus, D., 2008. Geochemical tracers to evaluate hydrogeologic controls on river salinization. Ground Wat. 46, 489-501. 
Parkhurst, D.L., Appelo, C.A.J., 1999. User's guide to PHREEQC (Version 2) - A computer program for speciation, batch-reaction, one-dimensional transport, and inverse geochemical calculations. U.S. Geological Survey Water Resources Investigations Report 99-4259.

Payero, J.O., Yonts, S.D., Irmak, S., Tarkalson, D., 2005. Advantages and disadvantages of subsurface drip irrigation. Extension of University of Nebraska Lincoln EC776.

Pelt, E., Chabaux, F., Innocent, C., Navarre-Sitchler, A.K., Sak, P.B., Brantley, S.L., 2008. Uraniumthorium chronometry of weathering rinds: Rock alteration rate and paleo-isotopic record of weathering fluids. Earth Planet. Sci. Lett. 276 (1-2), 98-105.

Phillips, F.M., Hogan, J.F., Mills, S.K., Hendrickx, J.M.H., 2003. Environmental tracers applied to quantifying causes of salinity in arid-region rivers: results from the Rio grande, southwestern USA. In: Water Resources Perspectives: evaluation, Management and Policy. (Eds.) Alsharhan, A.s., Wood, W.W.. New York, Elsevier Science, p. 327-334.

Picchioni, G. A., Karaca, H.,Boyse, L. G.,McCaslin, B. D.,Herrera, E. A., 2000. Salinity, Boron, and Irrigated Pecan Productivity along New Mexico's Rio Grande Basin. Journal of Environment Quality 29, 955-963.

Ragab, R., Prudhomme, C., 2002. Climate change and water resources management in arid and semi-arid regions: Prospective and challenges for the $21^{\text {st }}$ century. Biosystems Engineering 81, 3-34.

Rasouli, F., Pouya, A.K., Cheraghi, S.A.M., 2012. Hydrochemistry and water quality assessment of the Kor-Sivand Basin, Fars province, Iran. Environ. Monit. Assess. 184, 4861-4877.

Sevostianova, E., Leinauer. B., Sallenave, R., Karcher, D., Maier, B., 2011. Soil salinity and quality of sprinkler and drip irrigated warm-season turfgrasses. Agronomy Journal 103, 1773-1784.

Shanley, J.B., Mayer, B., Mitchell, M.J., Michel, R.L., Bailey, S.W., Kendall, C., 2005. Tracing sources of streamwater sulfate during snowmelt using $\mathrm{S}$ and $\mathrm{O}$ isotope ratios of sulfate and ${ }^{35} \mathrm{~S}$ activity. Biogeochemistry 76, 161-185.

Sheta, A.S., Al-Sewailem, M.S., Sallam, A. Sh., Al-Mashhady, A.S., 2000. Nature and composition of newly formed precipitates in relationship to characteristics of groundwater in arid environment. Arid Soil Research and Rehabilitation 14, 387-401.

Sigman, D.M., Casciotti, K.L., Andreani, M., Barford, C., Galanter, M., Bohlke, J.K., 2001. A bacterial method for the nitrogen isotopic analysis of nitrate in seawater and freshwater. Analytical Chemistry 73, 4145-4153.

Simpson, C.R., Nelson, S.D., Melgar, J.C., Jifon, J., King, S.R., Schuster, G., Volder, A., 2014. Growth response of grafted and ungrafted citrus trees to saline irrigation. Scientia Horticulturae 169, 199205.

Skrzypek, G., 2013. Normalization procedures and reference material selection in stable HCNOS isotope analyses - an overview. Analytical and Bioanalytical Chemistry 405, 2815-2823.

Skrzypek, G., Sadler, R., 2011. A strategy for selection of reference materials in stable oxygen isotope analyses of solid materials. Rapid Commun. Mass Spectrom. 25, 1625-1630.

Szynkiewicz, A., Borrok, D.M., Skrzypek, G., Rearick, M. Isotopic studies of the Upper and Middle Rio Grande. Part 1 - Importance of sulfide weathering in the riverine sulfate budget. Chem. Geol. - in review.

Szynkiewicz A., Witcher J., Modelska M., Borrok D.B., Pratt L.M., 2011. Anthropogenic sulfate loads in the Rio Grande, New Mexico. Chem. Geol. 283, 194-209. 
Trock, W.L., Huszar, P.C., Radosevich, G.E., Skogerboe, G.V., Vlachos, E.C., 1978. Socioeconomic and institutional factors in irrigation return flow quality control volume III: Middle Rio Grande Valley case study. Environmental Protection Agency (Report EPA-600/2-78-174c).

Wilcox, L.V., 1957. Analysis of salt balance and salt-burden data on the Rio Grande. In: Duisberg, P.C. (Ed.), Problems of the Upper Rio Grande: An arid zone river: Socorro, Bew Mexico. U.S. Commission for Arid Resource Improvement and Development, Publication no. 1, p. 39-44.

Williams, A.J., Crossey L.J., Karlstrom, K.E., Newell, D., Person, M., Woolsey, E., 2013. Hydrogeochemistry of the Middle Rio Grande aquifer system - Fluid mixing and salinization of the Rio Grande due to fault inputs. Chem. Geol. 351, 281-298.

U.S. Army Corps of Engineers, 2011. Alternative analysis for the Rio Grande salinity management program. Prepared by CH2MHILL.

(http://www.nmenv.state.nm.us/swqb/documents/swqbdocs/LRG/Program/RioGrandeSalinityAlternat ivesAnalysis09-26-11.pdf)

Van den Akker, J., Simmons, C.T., Hutson, J.L., 2011. Salinity effects from evaporation and transpiration under flood irrigation. Journal of Irrigation and Drainage Engineering 137, 754-764.

Victòria, L., Otero, N., Soler, A., Canals, Á., 2004. Fertilizer characterization: isotopic data (N, S, O, C, and Sr). Environ. Sci. Technol. 38, 3254-3262.

Yuan, F., Mayer, B., 2012. Chemical and isotopic evaluations of sulfur sources and cycling in the Pecos River, New Mexico, USA. Chem. Geol. 291, 13-22.

Yuan, F., Miyamoto, S., 2008. Characteristics of oxygen-18 and deuterium composition in waters from the Pecos River in American Southwest. Chem. Geol. 255, 220-230.

Yuan, F., Miyamoto, S., Anand, S., 2007. Changes in major element hydrochemistry of the Pecos River in the American Southwest since 1935. App. Geochem. 22, 1978-1813.

Yuan, F., Maiyamoto, S., 2005. Dominant process controlling water chemistry of the Pecos River in American southwest. Geophys. Res. Lett. 32, L17406, doi: 10.1029/2005GL023359. 
Figure 1. A conceptual model of the hydrological cycle and anthropogenic impacts in the semi-arid portion of the Rio Grande watershed in our study area. Blue arrows indicate directions of water flow. The previously suggested major sources of salinity are as follows (e.g., Hogan et al., 2007; Szynkiewicz et al., 2011): (A) Natural flow of brines, saline groundwater, and/or deep saline fluids; (B) Anthropogenic salts from flood irrigation; (C) Geologic salts from weathering of crystalline/volcanic and sedimentary rocks in Upper Rio Grande.

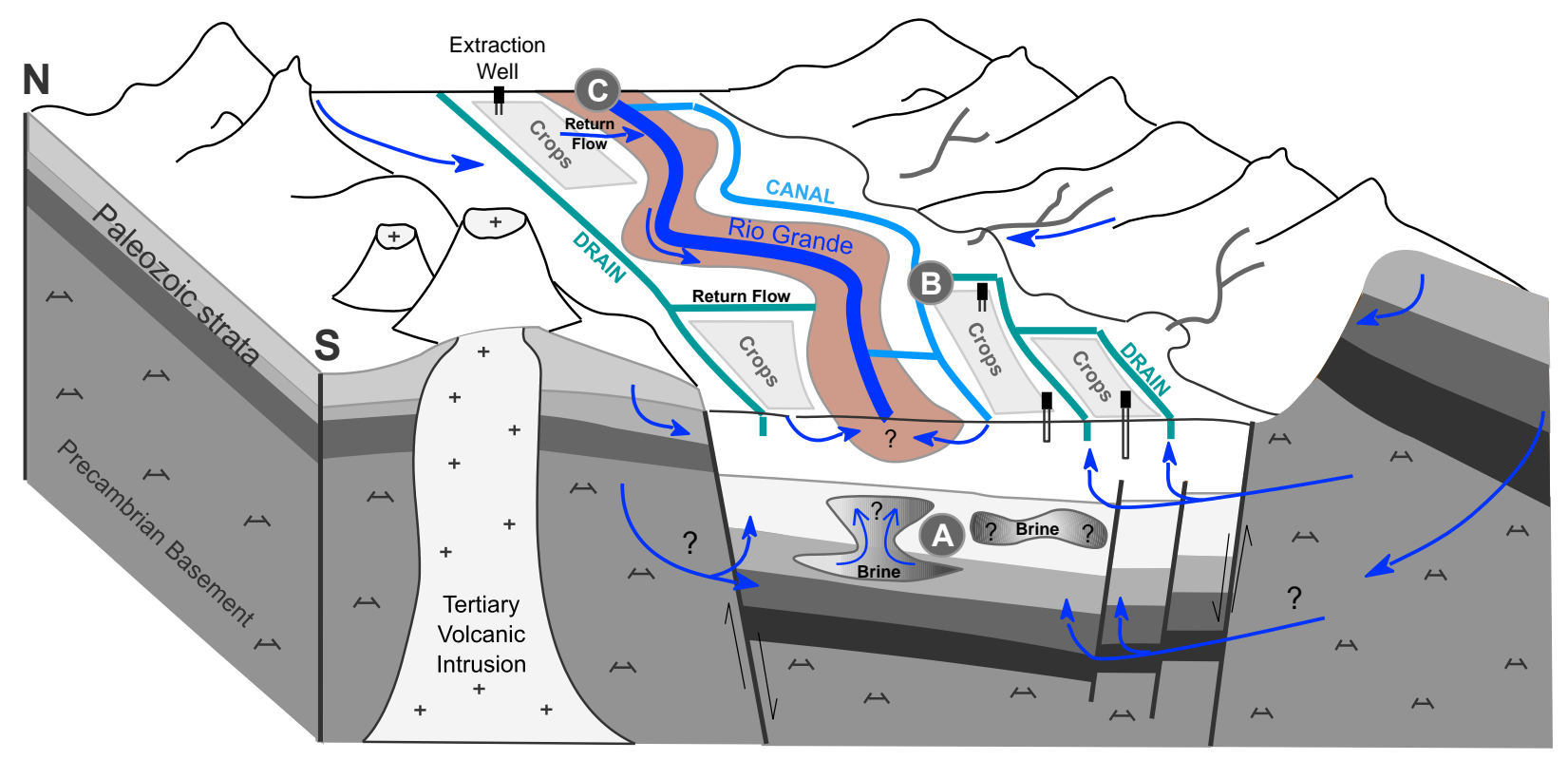


Figure 2. Simplified sketch (not to scale) showing the location of the water sampling points selected for seasonal observations (2010-2011) in the Mesilla (Loc. 16-20) and Hueco-Bolson basins (Loc. 53-54). The gray elongated areas around the Montoya drain indicate salt accumulation in the salt flat located in west El Paso. The distance between Radium Springs (\#16) and El Paso (\#20) is 90 km, and between El Paso (\#20) and Tornillo (\#54) is $\sim 65 \mathrm{~km}$.

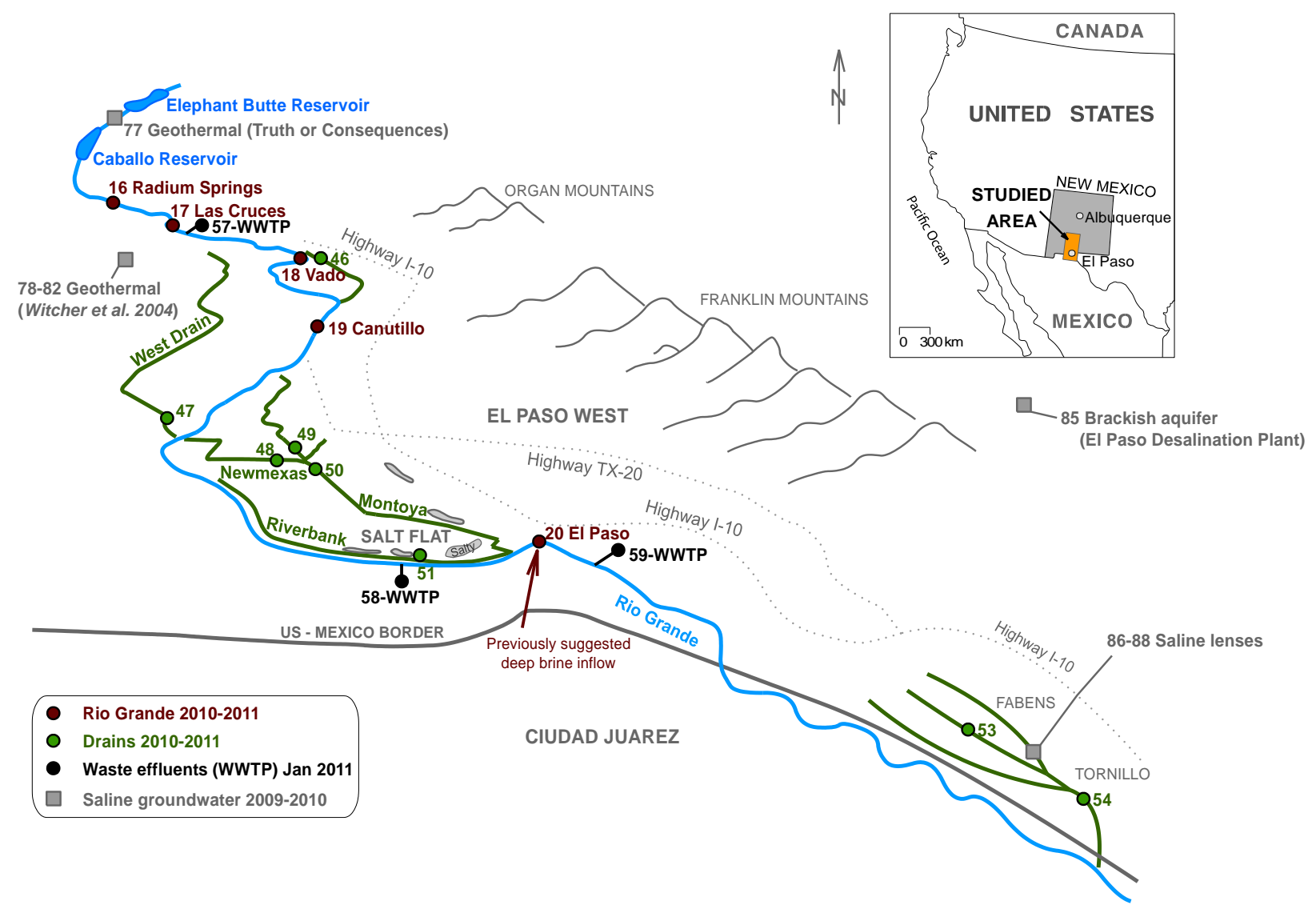


Figure 3. Variations of $\mathrm{SO}_{4}, \mathrm{Cl}$ and $\mathrm{HCO}_{3}$ concentrations in the analyzed water samples. Note that the concentrations of $\mathrm{SO}_{4}$ and $\mathrm{Cl}$ in saline groundwater from Fabens (Loc. 86, $\mathrm{SO}_{4}=4701 \mathrm{mg} / \mathrm{L}$ and $\mathrm{Cl}=150$ $\mathrm{mg} / \mathrm{L}$; Loc. 88, $\mathrm{SO}_{4}=1315 \mathrm{mg} / \mathrm{L}$ and $\mathrm{Cl}=9373 \mathrm{mg} / \mathrm{L}$ ) plot outside the concentration ranges presented on both plots. Concentrations for Locations 77-76 were adopted from Szynkiewicz et al. (Part 1 - this volume) and for Locations 78-82 from Witcher et al. (2004). The grey lines (1:1) are example projections of evaporation trends. See Figure 2 for the locations of sampling points.

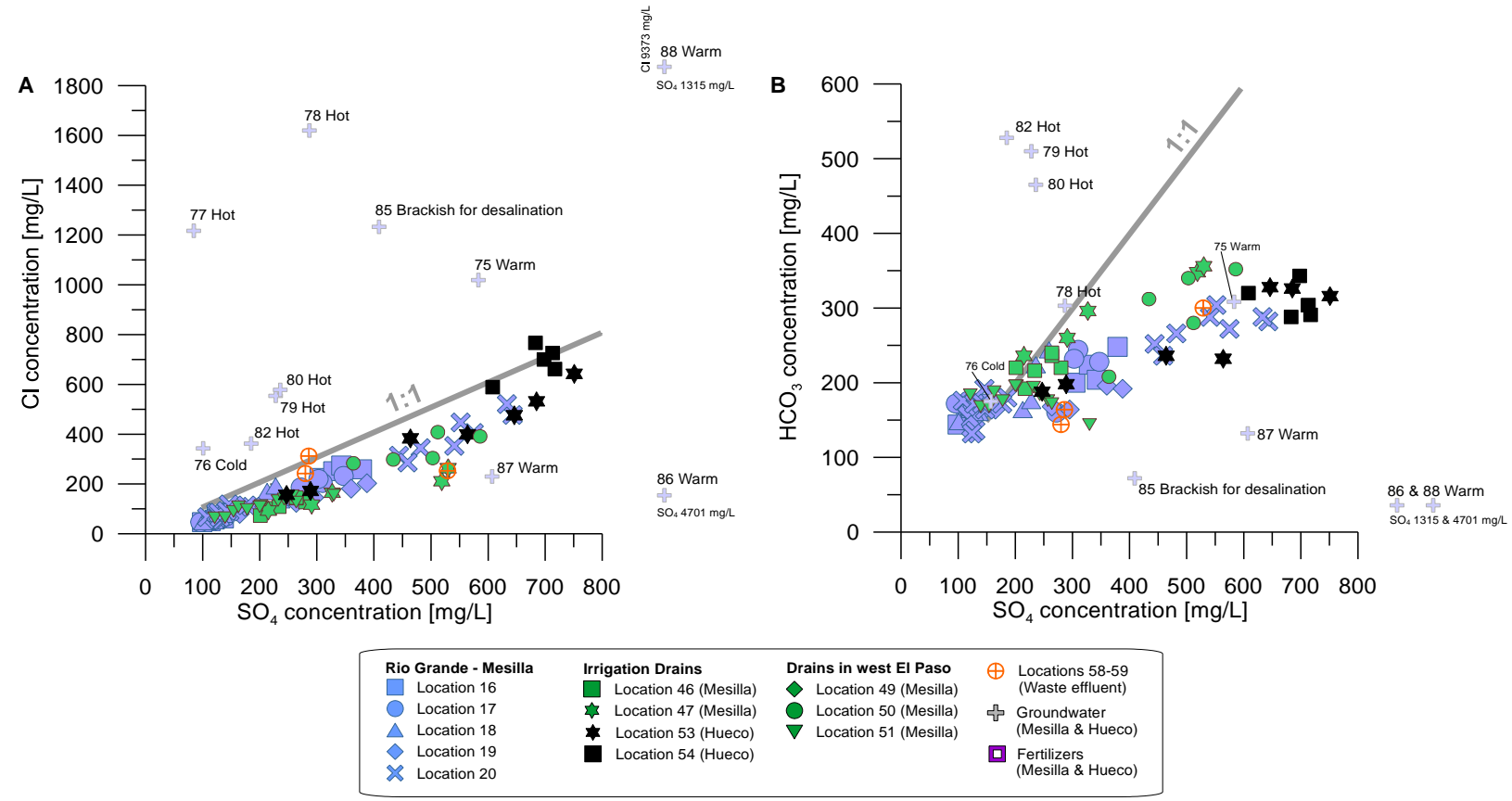


Figure 4. Seasonal variation of $\mathrm{NO}_{3}$ concentration in the Rio Grande in the Mesilla Valley (A) and in the sampled drains (B). The values of $\delta^{15} \mathrm{~N}$ and $\delta^{18} \mathrm{O}$ are presented for a few locations (with highest concentrations in November 2009 and April 2010) in the Mesilla and Hueco-Bolson basins and compared to isotope compositions of various nitrate sources after Kendall (1998) (C). See Figure 2 for the locations of sampling points.
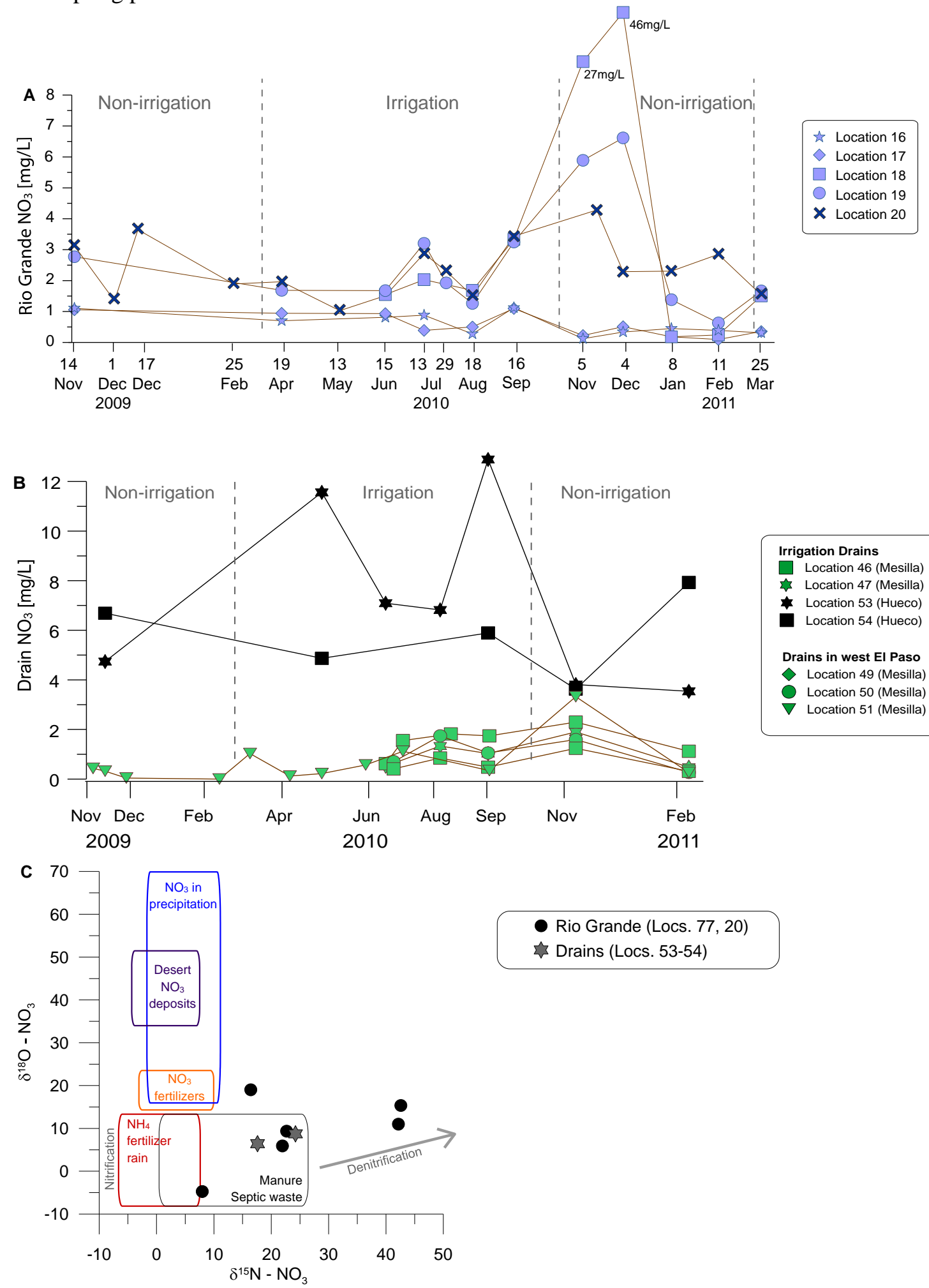

- Rio Grande (Locs. 77, 20)

Drains (Locs. 53-54) 
Figure 5. Seasonal variations of $\delta^{34} \mathrm{~S}$ and $\delta^{18} \mathrm{O}$ of $\mathrm{SO}_{4}$ (A and B) in the Rio Grande of the Mesilla Valley between Nov 2009 and Mar 2011. For comparison, variations of $\mathrm{SO}_{4}$ and $\mathrm{Cl}$ concentrations are presented (C and D). See Figure 2 for the locations of sampling points.
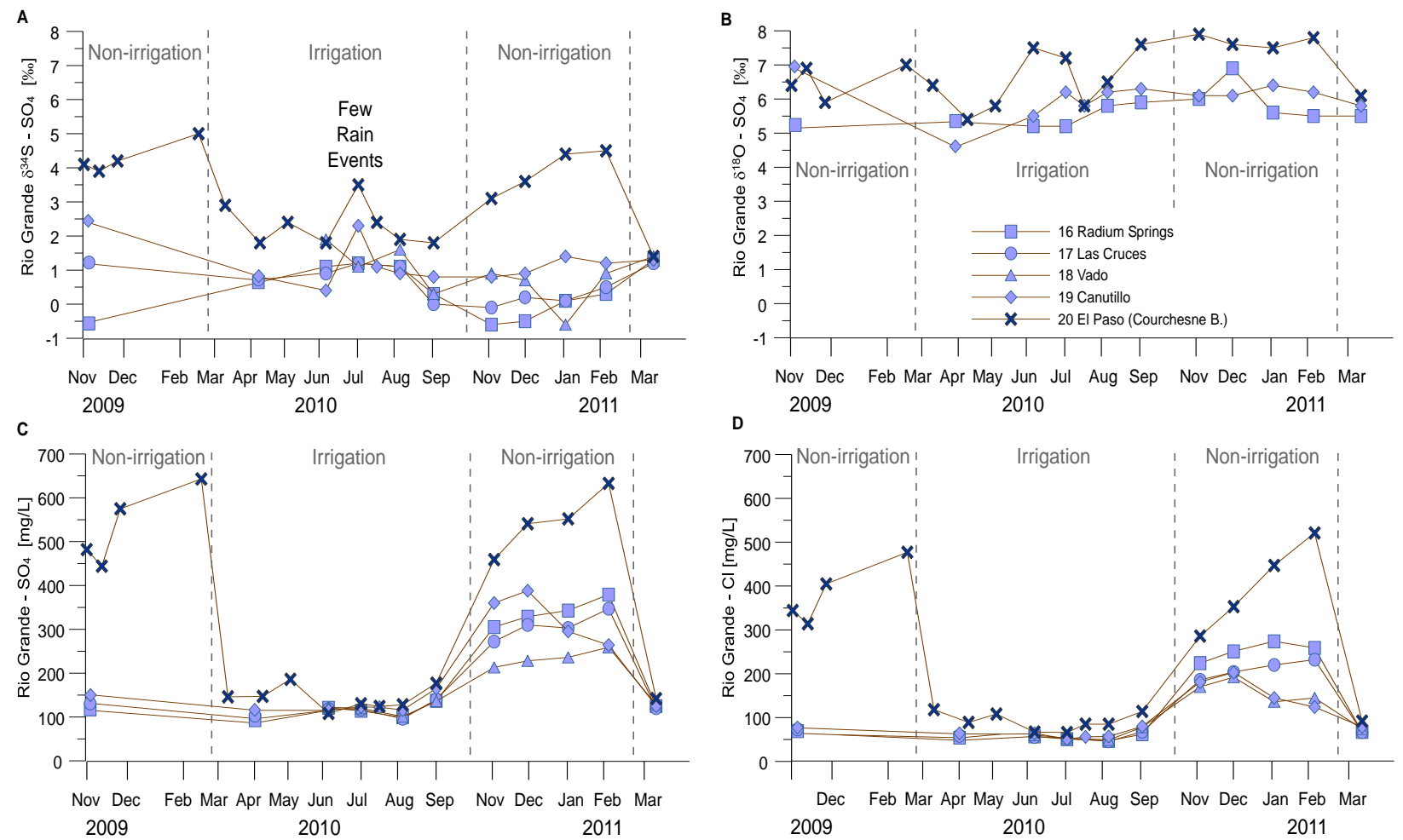
Figure 6. Seasonal variations of $\delta^{34} \mathrm{~S}$ and $\delta^{18} \mathrm{O}$ of $\mathrm{SO}_{4}$ (A and B) of sampled drains between Nov 2009 and $\mathrm{Feb}$ 2011. For comparison, variations of $\mathrm{SO}_{4}$ and $\mathrm{Cl}$ concentrations are presented (C and D). See Figure 2 for the locations of sampling points.
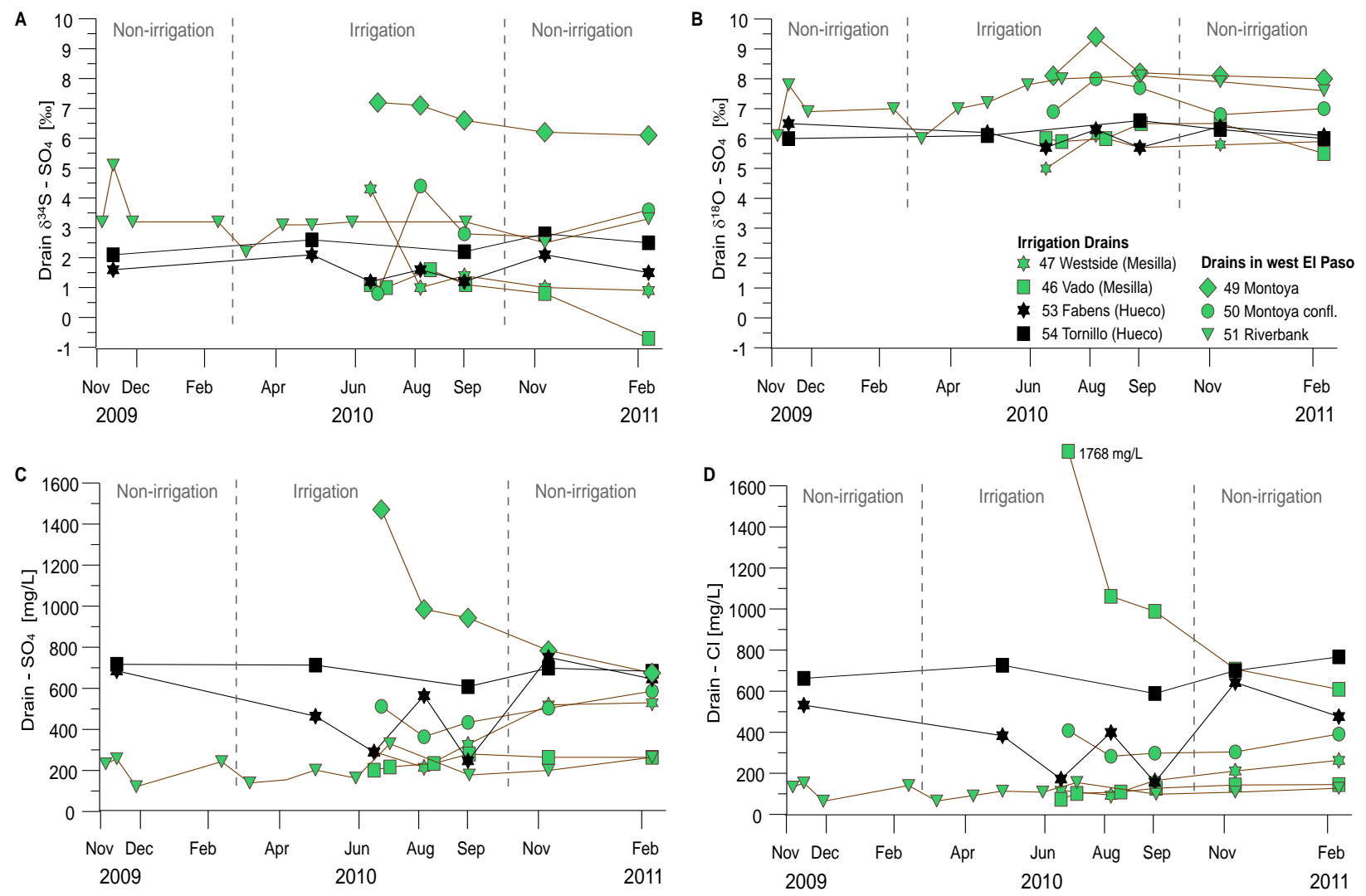
Figure 7. Variation of $\delta^{34} \mathrm{~S}$ versus $\delta^{18} \mathrm{O}$ in the Rio Grande, drains, fertilizers, saline groundwater, and waste effluents in the Mesilla and Hueco-Bolson basins. The grey regression line $\left(\mathrm{R}^{2}=0.68\right)$ between sulfide- and sulfate-derived $\mathrm{SO}_{4}$, and the $\delta^{34} \mathrm{~S}$ and $\delta^{18} \mathrm{O}$ of regional groundwater, upstream Rio Grande, and sedimentary/hydrothermal sulfide-derived $\mathrm{SO}_{4}$ endmembers are presented after Szynkiewicz at el. (Part 1- this volume). The blue dotted line indicates hypothetical mixing line between the Rio Grande surface water and low-temperature evaporite-derived $\mathrm{SO}_{4}$ which abundance increases downstream.

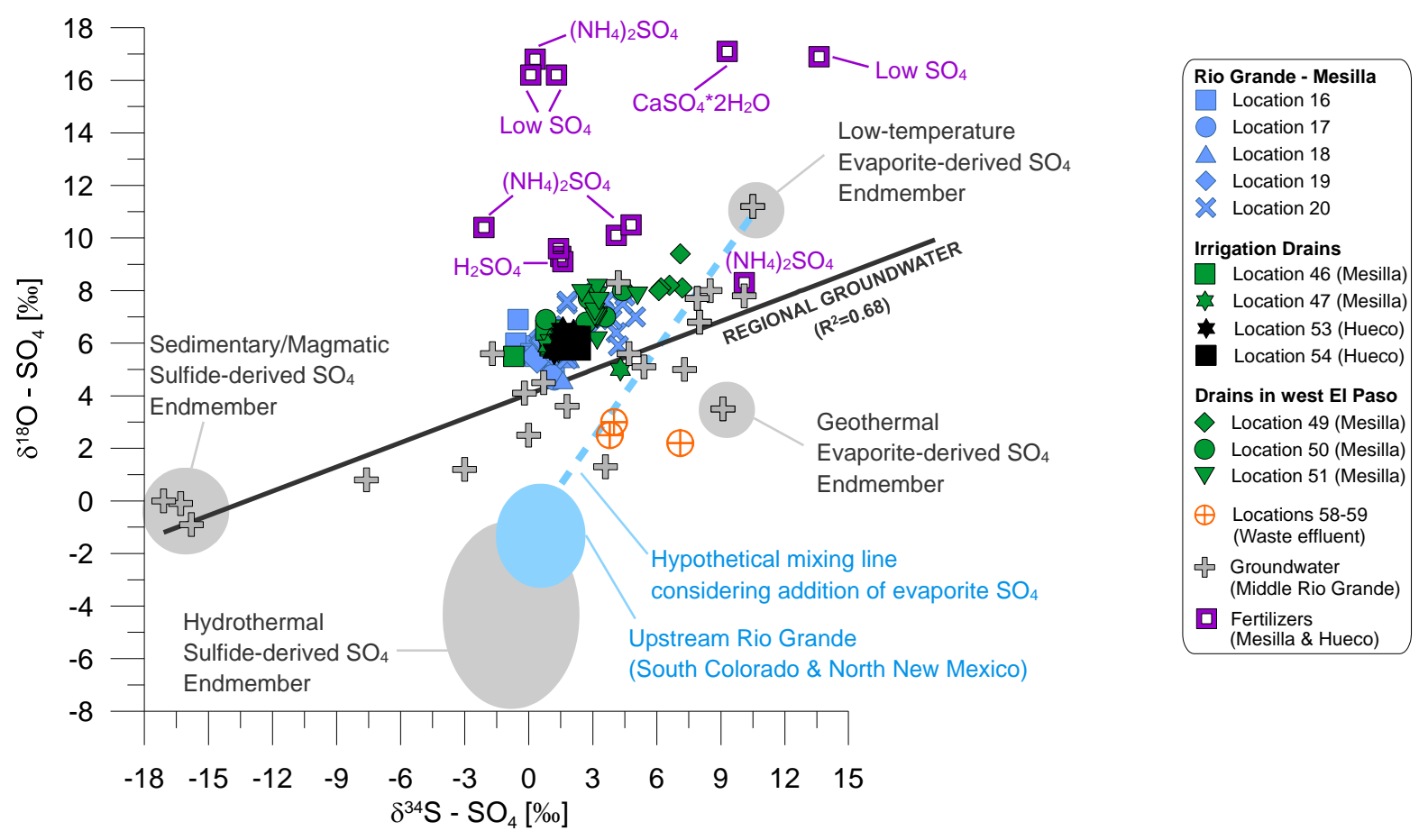


Figure 8. Variations of $\delta^{34} \mathrm{~S}$ and $\delta^{18} \mathrm{O}$ versus $\mathrm{SO}_{4}$ concentrations in the Rio Grande, agricultural/city drains, groundwater, waste effluents, and two major reservoirs in central/south New Mexico.
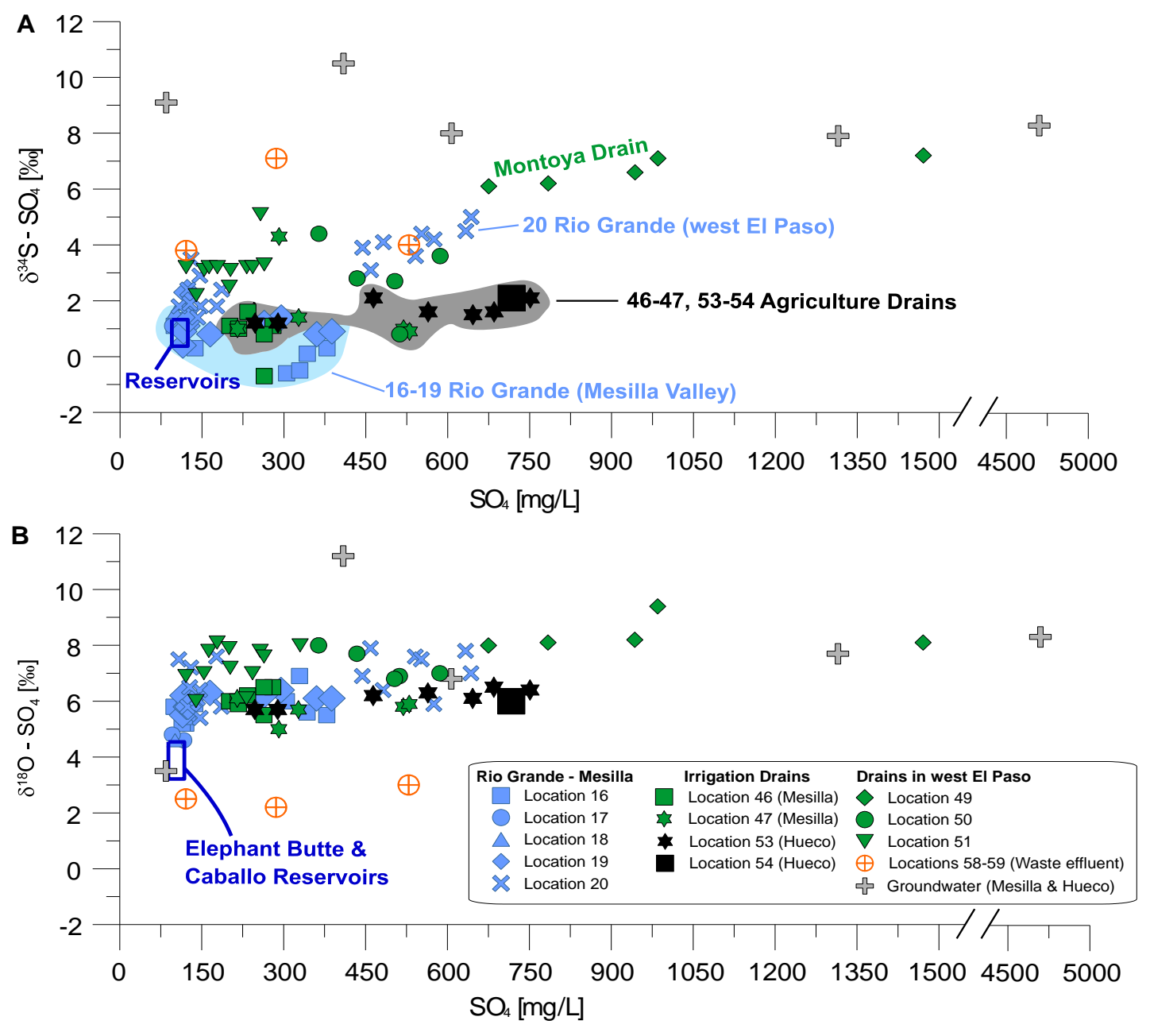
Figure 9. (A) Fluxes of $\mathrm{SO}_{4}$ and $\mathrm{Cl}$ in the Rio Grande at west El Paso (Loc. 20) and in the Tornillo Drain (Loc. 54) between Nov 2009 and Feb 2011. (B) Comparison of $\mathrm{SO}_{4}$ fluxes versus $\delta^{34} \mathrm{~S}-$ symbols and locations are same as on (A). See Figure 2 for the locations of sampling points.
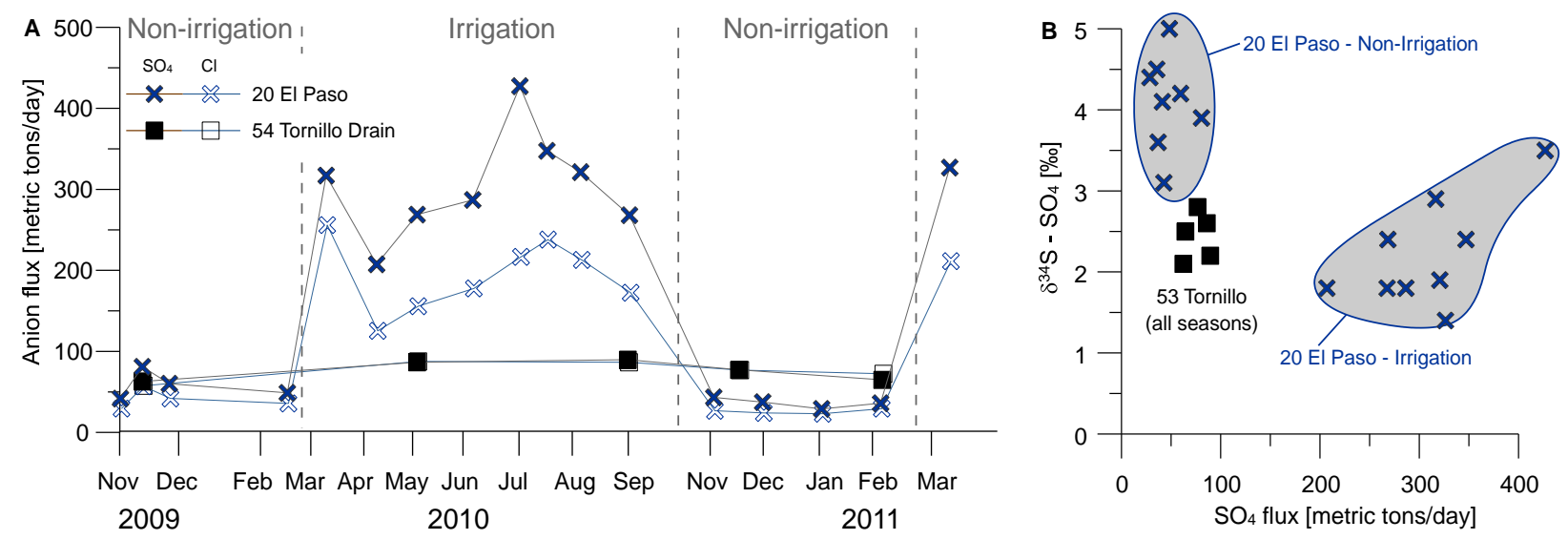
Figure 10. Seasonal variations of $\left({ }^{234} \mathrm{U}^{238} \mathrm{U}\right.$ ) activity ratios in the Rio Grande for Nov 2009 (nonirrigation) and Apr 2010 (irrigation) compared to the selected water samples of groundwater with elevated salinity, drains, and U-rich fertilizers. Numbers above symbols indicate sampling locations shown on Figure 2.

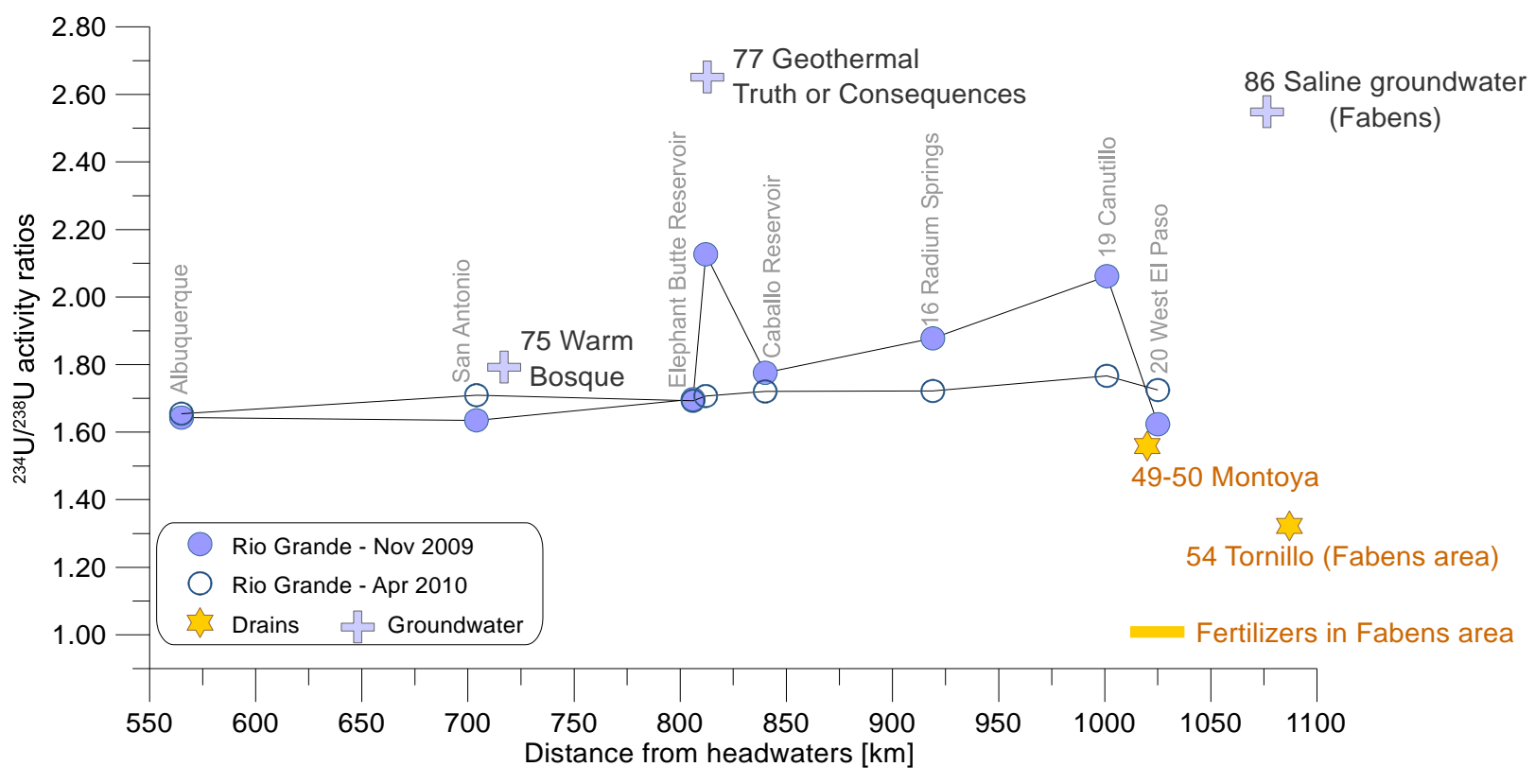


Figure 11. Calculated average saturation indices for calcite $\left(\mathrm{CaCO}_{3}\right)$, gypsum $\left(\mathrm{CaSO}_{4} \cdot 2 \mathrm{H}_{2} \mathrm{O}\right)$, thenardite $\left(\mathrm{NaSO}_{4}\right)$ and halite $(\mathrm{NaCl})$ with respect to distance downstream using PHREEQ ${ }^{\mathrm{TM}}$ (Parkhurst and Appelo 1999). Averages were calculated from samples collected at the same locations during different periods between 2009 and 2011 (Suppl. Table 1; Szynkiewicz et al. - Part 1 this volume). For clarity, error bars were not included.

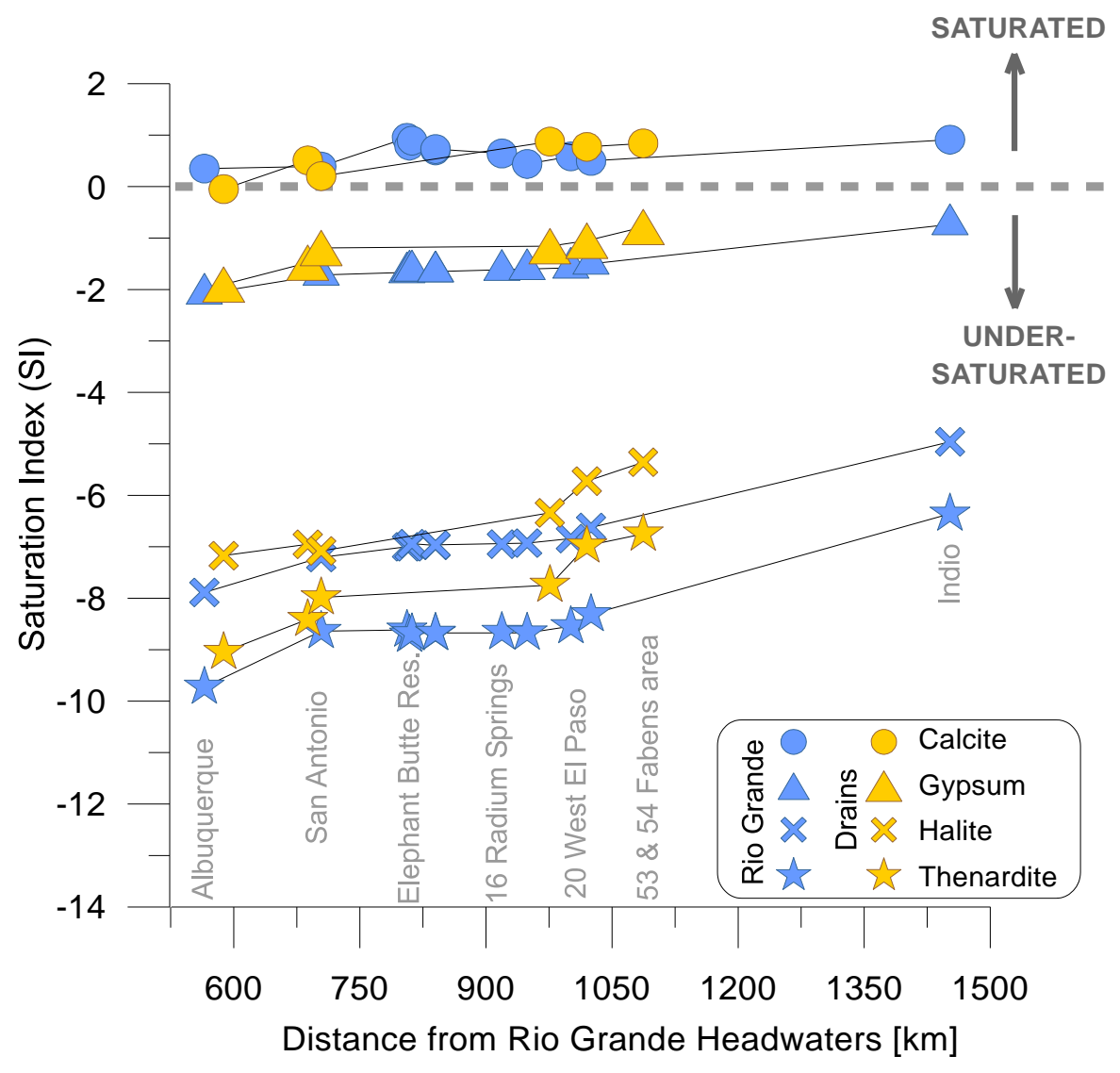




\begin{tabular}{|c|c|c|c|c|c|c|c|c|c|c|c|c|}
\hline Fertilizer & Description & & d34S [\%] & d180 [\%o] & SO4 [\%] & $\mathbf{S}[\%]$ & $\mathrm{Ca}[\%]$ & $\mathrm{K}[\%]$ & $\mathrm{Mg}[\%]$ & $\mathrm{Na}[\%]$ & $\mathbf{P}[\%]$ & Source \\
\hline Helena $12-0-0$ & Brown granules (ammonium iron sulfate) & Highly soluble & 4.1 & 10.1 & $>60$ & $>20$ & 0.01 & 0.03 & $<0.01$ & 0.04 & 0.009 & New data - this study \\
\hline Cotton 21-0-0 & White granules (ammonium sulfate) & Highly soluble & 0.3 & 16.8 & $>60$ & $>20$ & 0.02 & 0.02 & $<0.01$ & 0.02 & 0.155 & New data - this study \\
\hline Cotton 0-0-22 & Pinky white granules & Highly soluble & 10.1 & 8.3 & $>60$ & $>20$ & 0.2 & 2.72 & 10.9 & 0.55 & 0.014 & New data - this study \\
\hline F-White & White granules (ammonium sulfate) & Highly soluble & -2.1 & 10.4 & 73 & 24 & $<0.01$ & 0.03 & $<0.01$ & 0.01 & 0.005 & Szynkiewicz et al. (2011) \\
\hline F-Brown & Brown granules (ammonium sulfate) & Highly soluble & 4.8 & 10.5 & 74 & 24 & 0.02 & 0.03 & $<0.01$ & 0.02 & 0.005 & Szynkiewicz et al. (2011) \\
\hline Helena $20-0-20$ & White-brown-red hard grains & Low solubility & 4.3 & na & 48 & 16 & 0.06 & 5.13 & 0.17 & 0.1 & 0.017 & New data - this study \\
\hline Del City gypsum & White fine-grained gypsum & Low solubility & 9.3 & 17.1 & 56 & 19 & 23 & na & na & na & na & New data - this study \\
\hline Elemental Sulfur & Yellow coarse-grained pellets & Low solubility & 0.2 & na & na & 100 & na & na & na & na & na & New data - this study \\
\hline $16-8-3-4$ & Sulfuric Acid $(\mathrm{pH}<1)$ & Concentrated solution & 1.5 & 9.3 & 42 & 14 & 0.13 & 5.6 & 0.49 & 0.27 & 12 & Szynkiewicz et al. (2011) \\
\hline $24-40$ & Sulfuric Acid $(\mathrm{pH}<1)$ & Concentrated solution & 1.6 & 9.1 & 61 & 20 & 0.34 & 0.11 & 0.35 & 0.39 & 11 & Szynkiewicz et al. (2011) \\
\hline $5-0-0-10$ & Sulfuric Acid $(\mathrm{pH}<1)$ & Concentrated solution & 1.4 & 9.6 & 94 & 31 & 0.11 & 0.05 & 0.007 & 0.30 & 0.1 & Szynkiewicz et al. (2011) \\
\hline Helena 16-8-8 & White-brown-red hard grains ( $5 \% \mathrm{Fe}, 8 \% \mathrm{~Gy}$ ) & Low solubility & 5.1 & na & 25 & 8.4 & 2.11 & 3.58 & 0.29 & 0.27 & 4.73 & New data - this study \\
\hline Cotton 11-52 & Brown-white hard grains & Low solubility & 0.1 & 16.2 & 8 & 2.51 & 1.81 & 0.33 & 0.55 & 0.31 & 15.2 & New data - this study \\
\hline Helena 14-14-14 & White-brown-red hard grains & Low solubility & 8.9 & na & 19 & 6.34 & 1.51 & 5.1 & 1.96 & 0.4 & 3.81 & New data - this study \\
\hline Cotton $18-44-0$ & Brown hard grains & Low solubility & 1.3 & 16.2 & 6 & 2.05 & 2.08 & 0.17 & 0.4 & 0.32 & 14.2 & New data - this study \\
\hline Helena 20-4-8 & White-brown-red hard grains ( $5 \% \mathrm{Fe}, 8 \%$ Gy) & Low solubility & 13.6 & 16.9 & 14 & 4.73 & 2.53 & 4.97 & 1.06 & 0.27 & 2.59 & New data - this study \\
\hline Urea & White granules & Low solubility & $\mathrm{bd}$ & bd & 0.15 & 0.05 & 0.03 & 0.04 & 0.01 & 0.02 & 0.013 & New data - this study \\
\hline & & Average & 4.0 & 12.5 & 40.0 & 19.4 & & & & & & \\
\hline & & Median & 2.8 & 11.5 & 41.0 & 16.0 & & & & & & \\
\hline
\end{tabular}

